Discussion Paper No. 575

\title{
INTRA-FAMILY TRANSFERS IN JAPAN: \\ INTERGENERATIONAL CO-RESIDENCE, DISTANCE, AND CONTACT
}

\author{
Ken Yamada
}

The Fifth ISER-Moriguchi Prize (2003)

Awarded Paper

March 2003

The Institute of Social and Economic Research Osaka University

6-1 Mihogaoka, Ibaraki, Osaka 567-0047, Japan 


\title{
Intra-family Transfers in Japan:
}

\section{Intergenerational Co-residence, Distance, and Contact*†}

\author{
Ken Yamada ${ }^{\ddagger}$
}

March, 2003

\begin{abstract}
Classified broadly, two motives for intra-family transfers exist: altruism and selfishness. This paper examines two selfish hypotheses - the exchange motive (strategic bequest motive) and the demonstration effect - using a new Japanese micro data set. My analysis of the determinants of intergenerational co-residence, distance between residences, and frequency of contact yields considerable support for the exchange motive but no support for the demonstration effect. The findings are consistent with the exchange motive after distinguishing it from mutual altruism using a specific question.
\end{abstract}

Keywords: Intra-family transfers; Bequest motives; Co-residence JEL Classification: J1

*I am grateful to Fumio Hayashi, Daiji Kawaguchi, Colin Ross McKenzie, Hisahiro Naito, Fumio Ohtake, Jun Tomioka, and especially Charles Yuji Horioka, to anonymous referees of the ISER/Moriguchi Prize, and to participants of the CIRJE-TCER Macro Conference and of seminars at Hitotsubashi University and Osaka University for their valuable comments. I would also like to thank the Japan Institute of Life Insurance and the Social Science Japan Data Archive at University of Tokyo for allowing me to use their data. All errors are mine alone.

${ }^{\dagger}$ This paper received the 2003 Osaka University Institute of Social and Economic Research/Moriguchi Prize, which is awarded annually by the Institute of Social and Economic Research, Osaka University, to the best economics paper by a Japanese graduate student or by a foreign graduate student studying in Japan.

${ }^{\ddagger}$ Institute of Social and Economic Research, Osaka University, 6-1 Mihogaoka, Ibaraki, Osaka 567-0047, Japan; E-mail: kyamada@iser.osaka-u.ac.jp 


\section{Introduction}

The members of a family are linked via various channels. The links within an extended family are closer in East Asia than in Western Europe or the U.S. As evidence of the closeness of family ties in East Asia, intergenerational co-residence abounds despite showing a downward trend. ${ }^{1}$ In Japan, it is still common for children to live with their parents, and it is still rare for the elderly to live in an institution. Although closer links and interactions within families in Japan are well-known facts, empirical research on intra-family transfers is lacking in Japan. The reasons for the strong family ties in Japan have not yet been clarified. The motives for intra-family interactions have important implications for economic theory, fiscal policy, and income redistribution (Becker 1974, Barro 1974, Bernheim, Shleifer, and Summers 1985, and Altonji, Hayashi, and Kotlikoff 1992, 1996). At present, how to support the elderly in an aging society is an important policy issue.

This paper conducts an analysis of intergenerational transfers from children to parents in Japan using three measures: intergenerational co-residence, distance between residences, and frequency of contact. It is necessary to analyze not only the frequency of contact between family members living apart but also co-residence since a non-negligible proportion of Japanese live with their parents even after growing up. I analyze the determinants of co-residence, distance, and contact between parents and children with emphasis on the impact of bequest motives using micro data from the Survey on Life Planning in the Age of Long Life. This paper is the first research to use this data set.

This paper is organized as follows. The next section presents a literature review on intra-family transfers and summarizes the theoretical models and their empirical implications. I focus mainly on two strategic motives for intra-family transfers from children to parents. One hypothesis is the exchange motive (Bernheim, Shleifer, and Summers 1985 and Cox 1985) and the other is the demonstration effect (Cox and Stark 1995). Previous studies using U.S. data have obtained support for both hypotheses, even when the same data set is used. Previous studies using Japanese data also draw different conclusions.

Section 3 reviews the cultural background in Japan using data from two international comparative surveys. First, the International Comparative Survey on the Lives and Attitudes of the Elderly (ICSLAE) shows the closeness of family ties in Japan: The elderly in Japan are more likely to co-reside with their children. to see them frequently, and to expect family members to help out if

\footnotetext{
${ }^{1}$ See Cho and Yada (1994) and Masson, Tsuya, and Choe (1998). Research on intergenerational co-residence and contact in Japan is more common in sociology than in economics. However, sociological research does not test economic hypotheses and does not consider competing hypotheses.
} 
anything should happen to them than those in the U.S. and Germany. More than half of the elderly in Japan hope to co-reside with their children whereas hardly any of those in the U.S. do. Next, the Comparative Survey on Savings in Japan and the United States (Japan-U.S. Survey) shows the weakness of altruistic bequest motives and the importance of housing assets as bequeathable wealth in Japan. The proportion of those who plan to leave a bequest to their children no matter what in Japan is less than half of those in the U.S. is. The amount of inheritances in Japan is five times as large as those in the U.S. and housing assets comprise $85 \%$ of inheritances in Japan. Of those who own owner-occupied housing, $28 \%$ acquire it as a gift or an inheritance in Japan whereas this proportion is only $7 \%$ in the U.S.

Sections 4 and 5 describe the data and empirical strategy. The Survey on Life Planning in the Age of Long Life (SLPALL), which I use in my analysis, is the only available micro data set that collects information on intergenerational co-residence, distance between residences, and frequency of contact in Japan. This survey also collects direct information on the expectations and experience of receiving gifts and inheritances from one's parents. Joulfaian and Wilhelm (1994) examine the impact of inheritance expectations and experiences on labor supply and consumption but do not analyze bequest motives. I identify the exchange motive and mutual altruism using information pertaining to expectations concerning inheritances, past and future inheritance experiences from parents in connection with housing purchase and attitudes toward the care of parents. Moreover, I identify the demonstration effect using the characteristics of grandchildren. Section 6 presents the empirical findings. I find a strong positive association between inheritance expectations and coresidence and between financial assistance from parents and distance/contact. My findings suggest that intra-family transfers are consistent with the exchange motive and reinforce the empirical results of previous studies that Ricardian equivalence does not hold (Bernheim, Shleifer, and Summers 1985, and Altonji, Hayashi, and Kotlikoff 1992). Section 7 gives conclusions and implications.

\section{Theoretical Background and Empirical Evidence}

\section{A. The Exchange or Strategic Bequest Motive}

Becker (1974) shows that money transfers within the family of an altruistic parent will induce her selfish children to maximize family income. In other words, even selfish children will not take actions that decrease family income. Thus, a benevolent parent can realize her most preferred 
outcome without an elaborate incentive scheme no matter how selfish her children are. However, Bernheim, Shleifer, and Summers (1985) show that Becker's (1974) celebrated Rotten Kid theorem will not be valid if there is another interaction - namely, attention from children to parents. In particular, they show theoretically that an altruistic parent might attempt to elicit more attention from her children if he/she cares about not only her own consumption and her children's consumption but also about attention provided by her children. One possible strategic manipulation is that the parent pre-commits to a rule of bequest division and threatens to disinherit her children if they do not take care of her. From this point of view, bequests are a quid pro quo for care during old age. Bernheim, Shleifer, and Summers (1985) find empirically that the elderly in multiple-child families who hold bequeathable wealth elicit more attention from their children in the form of visits and telephone calls families using U.S. micro data from the Longitudinal Retirement History Survey.

Bernheim, Shleifer, and Summers (1985) and Cox (1985) set up models of the exchange motive. The parent cares about her own consumption, the attention or services provided by her child, and her child's utility, and the child cares about his own consumption and attention he provides to his parent. The parent's utility is increasing in her own consumption and attention provided by her child, and the child's utility is increasing in his own consumption and decreasing in attention he provides. The parent decides the consumption amount of each family member, the amount of bequests or inter-vivos transfers, and the amount of attention so as to maximize her own utility subject to a family budget constraint and a participation constraint or threat point. The family budget constraint is obtained by summing the budget constraints of the parent and child and allows money transfers from the parent to the child (inter-vivos transfers or bequests). The participation constraint expresses the condition that the child's utility when he provides attention to his parent and receives a bequest must equal or exceed the level of his utility when he provides no attention to his parent and receives the minimum bequest (the bequest he receives when he provides no attention). ${ }^{2}$ If the parent has two and more children, the optimal levels of consumption, bequests, and attention provided by children to their parent are attained when the participation constraint is binding (Bernheim, Shleifer, and Summers 1985). Alternatively, if the parent has dominant bargaining power, the level of the child's utility will equal the level of his utility when his consumption equals his endowment plus the minimum inter-vivos transfers and he provides no attention (Cox 1987).

The empirical implications of this model are that parental income and wealth will have a positive

\footnotetext{
${ }^{2}$ This model assumes that the incentive constraint is not binding - that is, that the parent succeeds in eliciting attention from her child without increasing the amount of bequeathable wealth.
} 
effect on attention and that filial income and wealth will have a negative effect on attention. If parental income or wealth increases, parents should elicit more attention from their children as long as attention is a normal good because children will provide more attention to their parents in the expectation of receiving a higher return. A decrease in filial income or wealth implies a decrease in the price of attention, and thus parents should elicit more attention from their children. In addition, children should provide more attention to their parents as their probability of receiving an inheritance increases - that is, children expecting to receive a bequest should be more likely to take care of their parents. The exchange motive is a falsifiable hypothesis as long as there is no substitute for attention provided by children to their parents in the market.

\section{B. The Demonstration Effect}

Cox and Stark (1995) presume a world in which children imitate their parent's behavior with some probability. All members of a family - parent, child, and grandchild - are selfish. Nonetheless, farsighted rational parents (child) provide attention to their grandparents (parent) since they (child) want to set an example for their children (grandchild) concerning the care of parents during old age. Young children (grandchild) observe their parents (child) taking care of their grandparents (parent), which provides a reference course of action. ${ }^{3}$ According to the demonstration-effect hypothesis, even if individuals (child) are selfish, they (child) will demonstrate devotion to their parents (parent) for the purpose of eliciting attention from their children (grandchild) in the future.

This ingenious hypothesis proposed by Cox and Stark (1995) has several implications. First, the presence of grandchildren should positively affect intergenerational transfers from children to parents. Second, the composition of upstream transfers is important. Visible transfers are much more effective, and thus in-kind transfers are more effective than cash, and visits are more effective than telephone calls. Third, individuals with longer life expectancies have more incentive to manipulate their children's preferences because the period of time during which they can potentially rely on their children is longer. ${ }^{4}$ In general, women have a longer lifespan than men, and wives are younger than husbands, and thus women should provide more attention to their parents than men.

Moreover, in the case of the demonstration effect, intra-family transfers from children to parents would be affected by the presence of grandchildren who live with the children to a greater extent than

\footnotetext{
${ }^{3}$ Cox and Stark (1995) provide many kinds of persuasive evidence supporting the premise of the demonstration effect that children imitate their parents' behavior.

${ }^{4}$ See Jellal and Wolff (2000) for a mathematical proof.
} 
by the presence of grandchildren who live apart from the children because grandchildren should be better able to observe the behavior of children if they live together. Similarly, intra-family transfers should not be affected by the presence of grandchildren who are too young to observe and remember their parent's behavior. Note that the characteristics of grandchildren also affect upstream transfers in the case of the exchange motive. Those who have small children have an incentive to have more frequent contact with their parents because their parents can help with child rearing and housework.

Cox and Stark (1995) obtain empirical findings that are consistent with the demonstration-effect hypothesis using U.S. micro data from the National Survey of Families and Households (NSFH). One of their findings is that those who experienced co-residence with their grandparents in early life tend to experience temporary or continued co-residence with their parents and have a positive opinion concerning co-residence with their elderly parents. The other is that those who have a child tend to have more frequent contact with their parents and to have a higher proportion of visits as compared with telephone calls. These findings bear out the premise and key implication of the demonstration effect.

Wolff (2001) also finds a positive effect of the presence of grandchildren on contact with parents using French micro data. In addition, Wolff (2001) uncovers a hidden relationship - namely, a positive effect of care of grandchildren by parents on contact with parents. Thus, it appears that those with small children live with their parents not in order to provide a role model to their children but in order to receive assistance with childcare from their parents. In short, Wolff (2001) provides an alternative explanation of the positive effect of the presence of grandchildren on contact with parents along the lines of the exchange motive rather than the demonstration effect.

Becker and Murphy (2000) present a new model that illustrates the process using the concept of social norms that require children to support their elderly parents. In this model, as in the case of the demonstration effect, individuals spend resources in order to inculcate their children with social norms or values and to induce them to provide care and support in old age, but the investment does not necessarily demonstrate devotion to their parents. The demonstration effect is one of the most effective ways of inculcating norms into one's children's minds, but not the only way.

\section{The Exchange Motive vs. the Demonstration Effect}

Cox and Stark (1995) claim that the insightful hypothesis presented by Bernheim, Shleifer, and Summers (1985) does not contain an enforcement mechanism whereas the demonstration-effect hy- 
pothesis does. According to the demonstration-effect hypothesis, parents inculcate family norms into their children's minds. Implanted monitors (a sense of guilt) play a self-enforcing role. Cox and Stark (1995) claim that, in the case of the exchange motive, children will take care of their parents only when their parents have ample financial assets, life insurance, or residential properties and that such a monetary mechanism does not work in non-wealthy families. However, even if parents do not have ample wealth, they can transfer time - for an example, housework, childcare, house sitting, etc. $^{5}$

Perozek (1998) reexamines the strategic bequest motive using the 1987 NSFH, whereas Cox and Stark (1995) use the NSFH conducted between March 1987 and May 1988. It is interesting to note that Perozek's results support the strategic bequest motive and thus that the two studies support different hypotheses even though they use approximately the same data. Furthermore, Cox and Rank (1992) also use the NSFH conducted between March 1987 and May 1988 and conclude that the motives for inter-vivos transfers are more consistent with exchange than altruism: the probability of net money transfers from parents to children are negatively correlated with filial earnings, while the amount of net money transfers from parents to children are positively correlated with filial earnings, the frequency of contact by children with parents and in-laws, informal help by children to parents, and geographic distance used as a proxy for care from children to parents. In addition, one of the empirical results of Cox and Stark (1995) and Wolff (2001) suggests altruism: parental (imputed permanent) income is negatively correlated with the frequency of contact with parents. Cox and Stark (1995) do not deny altruism; in fact, they give another explanation for the positive effect of the presence of grandchildren on contact with parents: altruistic feelings might burgeon inside of parents (child) by virtue of the presence of children (grandchild).

Altonji, Hayashi, and Kotlikoff (1992) reject the pure altruism that legitimizes the infinite horizon (dynasty) model presented by Barro (1974), but Altonji, Hayashi, and Kotlikoff (1992, 1996) acknowledge that impure altruism exists despite the inadequate amount of intra-family transfers.

\footnotetext{
${ }^{5}$ Moreover, families in which various interactions are repeated contain an enforcement mechanism $a b$ initio, and in the case of the exchange motive, interactions within a family are repeated, and punishments are possible. Recent experimental studies on economic transactions have found that reciprocity and fairness are more likely to arise in the case of non-anonymity and iteration. See Fehr and Gächter (2000), for example. Parents can threaten not to care for their grandchildren, do housework, or leave a bequest unless their children provide attention, and children can threaten not to provide attention to their parents unless their parents take care of their children, do housework, or promise an inheritance. Needless to say, wealthy parents can threaten their children with disinheritance. On the other hand, in the case of the demonstration effect, interactions within a family are not repeated since intra-family transfers are upstream unilateral. Thus, the demonstration effect is an imperfect self-enforcing mechanism that relies solely on individual monitors (a sense of guilt). Therefore, the exchange motive has a more effective enforcement mechanism than the demonstration effect.
} 
Thus, the empirical evidence to date has been mixed, with some support for all three models (the demonstration effect, exchange motive, and altruistic models).

\section{Altruism}

The dynasty model (Becker 1974, Barro 1974) assumes unidirectional altruism (parental altruism toward their children) only, and thus it can explain only intra-family transfers from parents to children. In practice, however, children might harbor altruism toward their parents as well. If mutual (bilateral) altruism exists within families, Ricardian equivalence does not hold (Altonji, Hayashi, and Kotlikoff 1992). It is extremely difficult to derive empirical implications that distinguish the exchange motive from mutual altruism and to test them.

\section{E. Evidence from Japanese Micro Data}

There exist two remarkable papers that analyze intra-family transfers using Japanese micro data - Hayashi (1997) and Ohtake and Horioka (1994). Hayashi (1997) examines the demand neutrality hypothesis based on pure altruism using data on Japanese extended families from the 1984 National Survey of Family Income and Expenditure (Zenkoku Shouhi Jittai Chousa) conducted by the Management and Coordination Agency (Soumu-shou), Japan. Hayashi (1997) shows that the allocation of resources between the two generations affects the food consumption patterns of two-generation households. As the older generation's income share increases, expenditures on food items preferred by the old - cereal, seafood, and vegetables - increase while that on eating out (preferred by the young) decreases and those on meat and dairy products are not significantly affected. These results violate demand neutrality.

Ohtake and Horioka (1994) examine the impact of the presence of bequest motives on the saving behavior of the elderly and the impact of bequest motives on upstream intra-family transfers financial support and co-residence - using data on households with a head aged sixty or older from the 1986 Basic Survey on the Life of the People (Kokumin Seikatsu Kiso-chousa) conducted by the Ministry of Welfare (Kousei-shou), Japan. Ohtake and Horioka's (1994) first analysis confirms the presence of bequest motives in Japan: the presence of children slows the speed of elderly parents' decumulation of their housing assets but not of their financial assets. Second, Ohtake and Horioka (1994) examine the determinants of financial support from children to parents. They find that the probability of money transfers is negatively correlated with parental labor income and pension 
income but that the amount of money transfers is positively correlated with financial net worth, which is consistent with the exchange motive. Finally, Ohtake and Horioka (1994) test the strategic bequest motive using data on co-residence. They find that the elderly who have more housing assets are more likely to live with their children, which supports the strategic bequest motive.

Hayashi (1997) analyzes the determinants of money transfers received and co-residence for the young aged twenty-five to fifty-four years old and the old fifty-five years old or older. He finds that money transfers received and co-residence are negatively correlated with labor income and pension income for the old, contrary to Ohtake and Horioka (1994). These results favor altruism.

One difference between the two studies is in the definition of co-residence. Hayashi (1997) uses the full sample of households when analyzing the determinants of co-residence whereas Ohtake and Horioka (1994) use the sample of non-coresident and quasi-coresident households (households in which parents and children live together but maintain separate accounts) in order to use information on the economic status of individual family members living in extended families. Another related difference is that Hayashi (1997) does not include wealth in his explanatory variables whereas Ohtake and Horioka (1994) do.

\section{Cultural Background}

Intra-family transfers and bequeathable wealth in Japan have many unique features. I clarify the uniquely Japanese features by showing the cultural differences between the U.S. and Japan using two international comparative surveys, and finally, I briefly describe the legal and institutional features in Japan.

\section{A. The International Comparative Survey on the Lives and Attitudes of the Elderly}

The International Comparative Survey on the Lives and Attitudes of the Elderly (ICSLAE) (Kourei-sha no Seikatsu to Ishiki ni kansuru Kokusai Hikaku Chousa) has been conducted every five years since 1981 by the Management and Coordination Agency (Soumu-shou), Japan. The ICSLAE surveyed individuals aged sixty and older in the U.S., Japan, Germany, South Korea, and Thailand in 1996, and obtained 998, 1,183, 1,000, 1,004, and 1,030 responses, respectively. The response rate was $76.8 \%$ in Japan. This survey collects internationally comparative data on parent/child co-residence, the distance between the residences of parents and children, the frequency of 
contact between parents and children, and attitudes toward the family and reports some interesting facts (Office for Policy on the Aging of Society 1997).

First, the co-residence rate of the elderly, defined as the share of elderly individuals not living alone or as a couple, is $58.8 \%$ for men and $62.7 \%$ for women in Japan and $22.8 \%$ for men and $26.3 \%$ for women in the U.S. Thus, the co-residence rate of the elderly is much higher in Japan than it is in the U.S. The co-residence rate of the elderly decreases with age in the U.S. but increases with age in Japan. Elderly women are more likely to co-reside than elderly men in both the U.S. and Japan. The proportion of the elderly who live within ten minutes of their children is $34.4 \%$ in the U.S. vs. $20.3 \%$ in Japan. The distance between the residences of the elderly and their children affects the frequency of contact between them. $40.8 \%$ and $50.8 \%$ of the elderly who live within ten minutes of their children's residence see their children almost every day in the U.S. and Japan, respectively. On the other hand, $25.0 \%$ and $17.8 \%$ of the elderly who live more than three hours away from their children hardly ever see their children in the U.S. and Japan, respectively. I analyze the determinants of co-residence, distance, and contact between parents and children in terms of bequest motives in subsequent sections.

Second, the elderly in the U.S. expect close friends to help out if and when anything should happen to them to a greater extent than in Japan: $18.1 \%$ in the U.S. vs. $2.0 \%$ in Japan in the case of disease, $29.8 \%$ in the U.S. vs. $17.2 \%$ in Japan in the case of anxiety or trouble, $12.1 \%$ in the U.S. vs. $3.2 \%$ in Japan in the case of economic hardship. By contrast, the elderly in Japan rely on their spouses, children, and relatives to a greater extent than those in the U.S. if and when anything should happen to them. Furthermore, the elderly in Japan would like to see other family members more frequently than those in the U.S.: the proportion of the elderly who would like to live with their children or grandchildren is $4.0 \%$ in the U.S. vs. $54.2 \%$ in Japan, and the proportion of the elderly who would sometimes like to have a meal or conversation with their children or grandchildren is $38.0 \%$ in the U.S. vs. $72.6 \%$ in Japan. These facts suggest that the elderly's demand for attention provided by children is much higher in Japan than in the U.S.

\section{B. The Comparative Survey on Savings in Japan and the United States}

The Comparative Survey on Savings in Japan and the United States (Japan-U.S. Survey) (Chochiku ni kansuru Nichibei Hikaku Chousa), was conducted simultaneously in the U.S. and Japan in 1996 by the Ministry of Posts and Telecommunications (Yuusei-shou) Japan. The Japan-U.S. Survey 
surveyed households with a head who is twenty years old or older in the U.S. and Japan and obtained 1,243 and 1,508 responses, respectively. The response rate was $68.5 \%$ in the U.S. and $69.1 \%$ in Japan. This survey collects comparative data on bequest motives, bequest division, homeownership, and inherited assets for the U.S. and Japan (Institute for Posts and Telecommunications Policy 1997).

In some respects, the nature of bequest motives is different between the U.S. and Japan. The proportion of those who (a) plan to leave a bequest to their children if their children take care of them is $3.2 \%$ in the U.S. vs. $5.2 \%$ in Japan, the proportion of those who (b) plan to leave a bequest to their children no matter what is $39.9 \%$ in the U.S. vs. $15.6 \%$ in Japan, the proportion of those who (c) do not plan to make any special efforts to leave a bequest to their children but will leave behind whatever happens to be left over is $47.9 \%$ in the U.S. vs. $56.0 \%$ in Japan, the proportion of those who (d) do not plan to leave a bequest is $2.7 \%$ in the U.S. vs. $4.0 \%$ in Japan, and those who (e) do not know or have never given it thought is $6.3 \%$ in the U.S. vs. $19.2 \%$ in Japan. The proportion of those who select (b) is twice as high in the U.S. as it is in Japan. Thus, Americans have a much stronger bequest motive than the Japanese. The proportions of those who select (a), (c), or (d) are greater in Japan than they are in the U.S. Thus, the bequest motives of the Japanese are selfish or strategic compared with Americans. ${ }^{6}$ The proportion of those who select (a) increases with age in Japan: $11.8 \%$ for those aged seventy and older vs. $2.4 \%$ for those who are in the twenties.

Owner-occupied housing is very important as bequeathable wealth in Japan. The proportion of homeownership is similar in the two countries ( $64.7 \%$ in the U.S. vs. $62.8 \%$ in Japan), ${ }^{7}$ but the methods for acquiring housing assets are very different: $92.7 \%$ acquire housing assets by oneself and $5.8 \%$ acquire housing assets as a gift or an inheritance in the U.S., while the corresponding proportions are $65.8 \%$ and $28.0 \%$, respectively, in Japan. The homeownership rate dramatically increases with age in Japan (10.8\% in one's twenties to $83.6 \%$ in one's eighties) whereas it gradually increases with age until one's fifties (39.5\% in one's twenties to $79.0 \%$ in one's fifties) and decreases thereafter in the U.S (59.9\% in one's eighties). The average market value of real estate is higher in Japan than it is in the U.S.: 48.87 million yen in Japan vs. 16.81 million yen (converted using an exchange rate of 1 dollar $=110$ yen) in the U.S. The proportion of respondents who received inheritance differs little in the two countries (29.1\%, in the U.S. vs. $22.3 \%$ in Japan), but the composition and average market value of inherited assets are very different. In the U.S., inheritances consist mostly of financial assets and other assets excluding real estate: $16.7 \%$ receive residential

\footnotetext{
${ }^{6}$ See Horioka (2002) for a detailed discussion of bequest motives and division in the U.S. and Japan.

${ }^{7}$ The proportion of detached houses including land is $61.8 \%$ in the U.S. and $53.1 \%$ in Japan.
} 
structures, $17.4 \%$ receive residential land, $14.8 \%$ receive structures or land other than residential properties, $24.3 \%$ receive real assets, $88.0 \%$ receive financial assets, and $97.1 \%$ receive other assets, and $16.3 \%$ of the value of bequests consists of residential structures, $8.1 \%$ consists of residential land, $38.7 \%$ consists of structures or land other than residential properties, $1.6 \%$ consists of real assets, $8.2 \%$ consists of financial assets, and $26.8 \%$ consists of other assets. On the other hand, in Japan, inheritances consist mostly of structures and land: $59.1 \%$ receive residential structures, $85.0 \%$ receive residential land, $19.9 \%$ receive structures or land other than residential properties, $3.8 \%$ receive real assets, $23.7 \%$ receive financial assets and $1.7 \%$ receive other assets, and $4.6 \%$ of the value of bequests consists of residential structures, $23.7 \%$ consists of residential land, $56.8 \%$ consists of structures or land other than residential properties, $4.9 \%$ consists of real assets and $9.8 \%$ consists of financial assets. ${ }^{8}$ The average market value of inherited assets is higher in Japan than in the U.S. regardless of the kind of property: the average market value of all inherited assets is 10.89 million yen in the U.S. vs. 55.21 million yen in Japan. Furthermore, the purchase of housing assets is the dominant motive for household loans in both the U.S. and Japan. More than $70 \%$ of indebted households have housing- or land-related debt in both the U.S. and Japan, ${ }^{9}$ but the average amount of housing- or land-related debt is very different in the two countries -7.45 million yen in the U.S. vs. 17.78 million yen in Japan.

\section{Institutional Background}

These differences between the two countries might reflect differences in the legal and tax systems. Bequests are divided according to the decedent's will in both the U.S. and Japan except that each child is guaranteed a minimum share in Japan; in other words, it is not possible to disinherit a child completely in Japan. In the absence of wills, bequests are divided equally for each child in both countries. In practice, however, the voluntary forfeiture is common in Japan, which is evidence of the discretionary distribution of bequests. ${ }^{10}$ The gift tax is far heavier than the inheritance tax in Japan, with the exception of parental assistance with housing purchase. Thus, tax avoidance via inter-vivos transfers is more difficult in Japan than it is in the U.S. ${ }^{11}$

\footnotetext{
${ }^{8}$ This survey does not collect information on the average value of other assets in Japan.

${ }^{9}$ The proportion of indebted households is $58.6 \%$ in the U.S. vs. $36.2 \%$ in Japan.

${ }^{10}$ According to the survey on inheritances conducted in 1989 and 1991 by the Japan Institute of Life Insurance, the proportion of respondents who forfeited their right of inheritances even though their father left a bequest was $51.4 \%$ in the Tokyo metropolitan area and 28.6\% in Yamagata prefecture (Noguchi 1992).

${ }^{11}$ See Barthold and Ito (1992) for a detailed US-Japan comparison of gift and estate (inheritance) tax systems.
} 


\section{Data}

In this paper, I use Japanese micro data from the Survey on Life Planning in the Age of Long Life (SLPALL) (Chouju Jidai no Seikatsu Sekkei) conducted between June 24th and July 6th, 1992, by the Japan Institute of Life Insurance (Nihon Seimei Bunka Sentah). The SLPALL surveyed 3,500 randomly selected individuals aged twenty and older from throughout Japan and obtained 2,804 responses. The SLPALL collects information on with whom respondents live, the frequency of faceto-face contact with parents and in-laws, age, occupation, the work status of both spouses, economic status, children, current housing, whose funds were spent to purchase the respondent's current home, expected homeownership status twenty years from now, the expectation of inheriting a home, and attitudes toward inheritance. The SLPALL collects information on the following aspects of economic status: respondent's own income, household income, household financial assets, and whether or not the household has housing loans outstanding but not on each family member's share of household income and financial assets in co-resident households. Section 6 and Table 1 give the definitions of the dependent and explanatory variables used in the estimation, respectively.

Adopting Bernheim, Shleifer, and Summers' terminology, I explore the demand for bequests whereas Bernheim, Shleifer, and Summers (1985) explore the supply thereof. Our empirical strategy is to analyze the determinants of attention that respondents (referred to as child) provide to their parents (referred to as parent). The absence of information on parental characteristics such as education, health, and wealth is the major limitation of the SLPALL, but the SLPALL collects information on respondents' expectation of inheriting a home and attitudes toward inheritance. Their expectation of receiving an inheritance from their parents sheds light on the strategic bequest motive, and we can analyze distinguish between the strategic bequest motive and mutual altruism as motives for intra-family transfers using interacting other variables with it.

More specifically, I first assess whether or not respondents expect to receive an inheritance using the following question: "Do you plan to live in your own owner-occupied house twenty years from now? If you plan to live in your own owner-occupied house, how do you plan to obtain it?" Five answers are given: (a) gift or inheritance from your parents, (b) your own funds and financial assistance from your parents, (c) only your own funds, (d) already live in your own owner-occupied house, and (e) other. I classify (a) as inheritance expectations, and (b) as parental assistance expectations. Next, I assess whether or not respondents received a gift or inheritance from their parents using the following question: "If you live in a owner-occupied house, who is the owner of 
it and how did you obtain it (including residential land) if you are the owner?" Five answers are given: (a) parents, (b) children, (c) bought with my own and spouse's funds, (d) acquired it as gift or inheritance from parents or received parental financial assistance, and (e) other. I classify (d) as inheritance experience. Finally, I distinguish the strategic bequest motive from mutual altruism using the following question: "Would you like to take care of your aged parents even if you do not expect an inheritance from your parents?" Five choices are given: (a) yes, (b) if anything yes, (c) yes and no, (d) if anything no, and (e) no. I classify (a) as altruism, and (b), (c), (d), and (e) as exchange motive. I do not classify (b) as altruism because those who select (b) do not definitely plan to take care of their parents if they do not expect an inheritance and because it is difficult to answer "no" to such a question given traditional Japanese values. ${ }^{12}$

The availability of direct information on the expectation and experience of receiving a gift or inheritance and on altruistic feelings toward one's parents is the most important advantage of the SLPALL. The tests for bequest motives in previous studies are based on the correlation between the beneficiary's economic status and intra-family transfers. ${ }^{13}$ However, the drawback of this kind of test is that economic status such as income and wealth might be correlated with the degree of altruism. For example, the bequeathable wealth of the elderly might possibly be directly correlated with the degree of filial altruism and might also be indirectly correlated with the degree of filial altruism through portfolio selection that reflects the degree of time preference, risk aversion, and parental altruism. Even Bernheim, Shleifer, and Summers' (1985) result that attention provided by children is positively correlated with parental bequeathable wealth in multiple-child families but not in single-child families can be consistent with dual altruism since children with siblings might be altruistic whereas children raised as a single child might be selfish. Thus, it is very important to use direct information on gifts and inheritances and to control for the degree of filial altruism when we examine the determinants of co-residence, distance, and contact between parents and children.

After eliminating observations that have missing values, inconsistent responses, the unemployed, the divorced, and those for whom both parents and both parents-in-law have passed away, 1,221 observations remain. Table 2 shows sample means for the married and the unmarried. $90 \%$ of the unmarried live with their parents. The married have greater opportunity for contact with

\footnotetext{
${ }^{12}$ Among the 943 married respondents, $31.9 \%$ of respondents selected (a) yes, $43.1 \%$ selected (b) if anything yes, $19.7 \%$ selected (c) yes and no, $3.1 \%$ selected (d) if anything no, and $2.1 \%$ selected (e) no. If I classify (b) not as exchange motive but as altruism, the estimation results are the same concerning co-residence and roughly the same concerning the distance between residences and the frequency of contact.

${ }^{13}$ One exception is Altonji, Hayashi, and Kotlikoff (1992) who control for unobservable individual (dynasty) heterogeneity by estimating the consumption function after a first-differencing transformation.
} 
parents than the unmarried because they have parents-in-law, and there are also some differences in unobservable characteristics between the married and the unmarried. In addition, almost no unmarried individuals have children in Japan, and the SLPALL does not ask unmarried respondents whether or not they have children. Thus, I focus on the 943 married respondents in the subsequent analysis whereas Cox and Stark (1995) and Wolff (2001) include unmarried as well as married respondents in the sample they used for their regression analysis. Table 3 shows sample means for married respondents who co-reside with their parents and those who live apart from their parents.

Table 4 shows the summary statistics for the married respondents. Their average age is 36 , which is appropriate for testing the exchange motive and the demonstration effect. ${ }^{14}$ If the sample is biased toward the young, the positive correlation between the presence of grandchildren and co-residence or contact with parents is likely to reflect an exchange motive because their children are also young in the case of young couples. The average age of the sample used by Wolff (2001) is 26.5 years old. Moreover, I distinguish between the two selfish hypothesis using the characteristics of grandchildren that are closely related to the cost of child rearing and the visibility of parental behavior such as the age of the grandchildren, the employment status of the mother, and living arrangements.

\section{Estimation Methods}

The model I estimate is of the form:

$$
A_{i}^{*}=x_{i}^{\prime} \beta+u_{i}
$$

where $A_{i}^{*}$ represents an individual $i$ 's propensity to provide attention, help, respect, or visits to one's parents, $x_{i}$ represents a $k \times n$ observable vector where $k=$ the number of explanatory variables and $n=$ the number of observations, $\beta$ represents a $k \times 1$ estimated vector, and $u_{i}$ represents an unobservable error term. This estimation equation can be interpreted as a linear approximation of the participation constraint. We are not able to observe the individual's level of altruism even though the levels of filial altruism and parental altruism within families will affect the values of both dependent variables and some of the explanatory variables. Even if I could control for the

\footnotetext{
${ }^{14}$ The age distribution of the SLPALL sample is similar to those of the October and November 1992 issues of the Monthly Report on Current Population Estimates, which is conducted by the Management and Coordination Agency, Japan, except that respondents who are aged twenty to twenty-four years old or seventy-five years old or older are slightly underrepresented.
} 
individual's level of filial altruism, parental altruism will bias the estimators if correlated with both $A^{*}$ and $x$. Table 1 gives the definitions of all explanatory variables, and Table 4 shows their summary statistics. I utilize three measures of $A^{*}$ and three estimation models.

First, I utilize a binary response model as follows:

$$
\begin{aligned}
R_{i}^{*} & =x_{i}^{\prime} \beta_{1}+u_{1 i}, \\
R_{i}^{*} & =1 \text { if } R^{*}>0, \\
& =0 \text { otherwise, }
\end{aligned}
$$

where $R^{*}$ represents an individual or married couple $i$ 's propensity to co-reside with their parents, and $u_{1 i}$ has a normal distribution with mean zero and variance one. An alternative interpretation is that $R_{i}^{*}=1$ if the level of approximate linear indirect utility when one co-resides with one's parents exceeds that when one lives apart from one's parents and $R_{i}^{*}=0$ otherwise.

Second, I utilize an ordered response model as follows:

$$
\begin{aligned}
D_{i}^{*} & =x_{i}^{\prime} \beta_{2}+u_{2 i}, \\
D_{i}^{*} & =1 \quad \text { if } D_{i}^{*} \leq 0, \\
& =2 \text { if } 0 \leq D_{i}^{*}<d_{1}, \\
& =3 \text { if } d_{1} \leq D_{i}^{*}<d_{2}, \\
& =4 \text { if } d_{2} \leq D_{i}^{*}<d_{3}, \\
& =5 \text { if } D_{i}^{*}<d_{4},
\end{aligned}
$$

where $D_{i}^{*}$ represents an individual or married couple $i$ 's propensity to live close to their parents, $u_{2 i}$ has a normal distribution with mean zero and variance one, and $d_{j}$ is a latent parameter for $j=1,2$, 3, 4. I define geographic distance between an individual or married couple's own residence and their parents' residence as follows: too far to go and return in one day $=1$, close enough that one can go and return in one day $=2$, one hour one way by car, bus, or train $=3$, within walking distance $=$ 4 , and adjacent $=5$. I focus on married couples who live apart from both sets of parents. ${ }^{15}$

\footnotetext{
${ }^{15} \mathrm{I}$ also define co-residence $=6$ and examine the determinants of distance between respondents' residence and that of their parents. The signs and statistical significance of the estimated coefficients are the same as those of a probit regression analysis of co-residence with parents or in-laws except that the coefficient of inheritance experience becomes positive and statistically significant.
} 
Third, I utilize a truncated regression model as follows:

$$
\begin{aligned}
C_{i}^{*} & =x_{i}^{\prime} \beta_{3}+u_{3 i}, \\
C_{i}^{*} & =0 \quad \text { if } C_{i}^{*} \leq 0 \\
& =C_{i}^{*} \quad \text { if } 0<C_{i}^{*}<c_{\max }
\end{aligned}
$$

where $C_{i}^{*}$ represents an individual or married couple $i$ 's frequency of contact with parents and $u_{3 i}$ has a normal distribution with mean zero and variance $\sigma^{2}$. I quantify contact as follows: almost daily $=300$, once a week or more $=100$, once a month or more $=24$, three to four times a year $=3.5$, about once a year $=1$, and almost never $=0 .{ }^{16}$ Hence, $c_{\max }$ equals 300 when I use contact with the husband's parents and 600 when I use contact with both sets of parents. ${ }^{17}$ I focus on married couples who live apart from both sets of parents. Table 5 shows the summary statistics of the dependent variables.

\section{Estimation Results}

This section presents the estimation results of models (1), (2), and (3). The results are shown in Tables 5 through 14. Tables 5 through 9 show the estimation results for the determinants of intergenerational co-residence, distance between residences, and frequency of contact. Column 1 shows the result of a simple specification. Columns 2 through 6 identify mutual altruism and the exchange motive using the specific questions about inheritance expectations and attitudes toward the care of parents and show the results for five specifications of grandchildren's characteristics. Tables 10 through 14 show robustness checks using the basic specification of column 2 in Tables 5 through 9. More specifically, I estimate the basic specification for the subsample of males, that of females, that of those who live close to their parents and in-laws, that of those who live far from their parents and in-laws, and that of those who are forty and older.

\footnotetext{
${ }^{16}$ Cox and Rank (1992) and Cox and Stark (1995) quantify contact as follows: several times a week = 100, about once a week $=52$, one to three times a month $=24$, several times a year $=6$, about once a year $=1$, and not at all $=0$ and then aggregate across parents and in-laws. Bernheim, Shleifer, and Summers (1985) qualify attention $V$ as follows: $V=(4 \cdot$ the number of children who visit or telephone their parents weekly + the number of children who visit or telephone their parents monthly) / (4 t the number of children). $V$ measures contact per child and takes a value between 0 and 1 by definition.

${ }^{17} \mathrm{I}$ also define co-residence $=c_{\max }$ and examine the determinants of frequency of contact between respondents and respondents' parents. The signs and statistical significance of the estimated coefficients are the same as those of a probit regression analysis of co-residence with parents or in-laws except that the coefficient of inheritance expectations becomes highly statistically significant.
} 


\section{A. Co-residence}

Table 5 shows the results of a probit regression analysis of co-residence with parents or in-laws. I obtain several results that are consistent with the exchange motive, but almost no results support the demonstration effect. First, inheritance expectations have a positive impact on co-residence when entered in isolation, which is consistent with Ohtake and Horioka's (1994) result that the probability of co-residence is positively correlated with the amount of housing assets. Inheritance expectations are positively associated with co-residence even after filial altruism is controlled for. When inheritance expectations are interacted with the altruism and exchange motive dummies, the magnitude of the coefficient of the interactive term between inheritance expectations and the altruism dummy is smaller than that of the coefficient of inheritance expectations when entered in isolation, while that of the coefficient of the interactive term between inheritance expectations and the exchange motive dummy is larger, meaning that inheritance expectations affect those with an exchange motive more strongly than altruistic individuals. Both coefficients are statistically significant at the $1 \%$ level. Second, filial income has a negative impact on co-residence. Third, filial housing loans have a positive impact. Since a decrease in filial income and wealth implies a decrease in the opportunity cost to children of providing attention to their parents, parents can elicit more attention from their children when filial income and wealth decrease. These two results can also be interpreted as implying that co-residence is an inferior good, as Hayashi (1997) points out. In addition, the dual earner dummy has a positive impact on co-residence, which is consistent with Hayashi's (1997) result that the working wife dummy has a positive impact on co-residence and might also be interpreted as being consistent with the exchange motive. Since childcare facilities are inadequate in Japan, parental cooperation is very important for women who work after marriage and childbirth, and living with one's parents facilitates parental help with housework and child rearing.

Finally, the presence of grandchildren has no impact on co-residence overall, but the presence of pre-nursery school aged grandchildren has a positive and statistically significant impact on coresidence in the case of double-income couples. This result is consistent with the exchange motive because pre-nursery school aged children require more care than older children, meaning that the benefits of co-residence are higher, but is inconsistent with the demonstration effect because prenursery school aged children are presumably too young to observe and remember their parents' behavior. The number of grandchildren has a positive and statistically significant impact on coresidence, which is consistent with Hayashi's (1997) result that the number of non-adult children 
has a positive impact on co-residence. This finding is consistent not only with the exchange motive but also with the demonstration effect because, as the number of children increases, not only will the cost of child rearing increase but also the expected return from the demonstration effect. However, according to the demonstration effect, the impact of the presence of grandchildren should also have a positive and statistically significant.

Table 5 shows the estimated marginal effects of each factor on the probability of co-residence with parents or in-laws. I find that inheritance expectations have the greatest impact and that the coefficients of the interactive term between inheritance expectations and the exchange motive dummy is larger than that with the altruism dummy by $15 \%$. These results suggest that strategic children respond to their parent's signal of inheritance or the threat of disinheritance more sensitively

than altruistic children do. The dual earner dummy and the presence of pre-nursery school aged grandchildren in double income couples also have a substantial impact on co-residence.

\section{B. Distance}

Table 6 shows the results of an ordered probit regression analysis of the distance between the respondent's residence and that of the parents who live closer to the respondent. I obtain three results that are consistent with the exchange motive but no results that support the demonstration effect. First, inheritance expectations have a positive impact on distance, but when inheritance expectations are interacted with the altruism and exchange motive dummies, the coefficients of the interactive terms are not statistically significant. Second, inheritance experience has a positive impact on distance. Parents are more likely to provide financial assistance to their children the closer to the parents' residence is the house their children purchase. Third, filial income has a negative impact on distance. On the other hand, the impact of the presence of grandchildren is negative and statistically insignificant.

Table 7 shows the results of ordered probit regression analysis on distance between the respondent's residence and that of the husband's parents. I obtain three results that are consistent with the exchange motive but no results that support the demonstration effect. First, inheritance expectations have a positive impact on distance. When inheritance expectations are interacted with the altruism and exchange motive dummies, the magnitude of the coefficient of the interactive term between inheritance expectations and the altruism dummy is smaller than that of the coefficient of inheritance expectations when entered in isolation, while that of the coefficient of the interactive 
term between inheritance expectations and the exchange motive dummy is larger. The former is statistically significant at the $10 \%$ level, while the latter is statistically significant at the $1 \%$ level. In other words, inheritance expectations are positively associated with co-residence after filial altruism is controlled for. Second, inheritance experience has a positive impact on distance. Third, filial income has a negative impact. On the other hand, the impact of the presence of grandchildren is not statistically significant.

\section{Contact}

Table 8 shows the results of a Tobit regression analysis of the frequency of contact with parents or parents-in-laws. I obtain a result that consistent with the exchange motive namely, that inheritance experience has a positive impact on the frequency of contact, and a result that is inconsistent with the demonstration effect namely, that the impact of the presence of grandchildren is negative and statistically insignificant.

Table 9 shows the results of Tobit regression analysis of the frequency of contact with the husband's parents. The estimation results are similar to those in Table 7. I obtain three results that are consistent with the exchange motive but no results that support the demonstration effect. First, inheritance expectations have a positive impact on the frequency of contact. When inheritance expectations are interacted with the altruism and exchange motive dummies, the magnitude of the coefficient of the interactive term between inheritance expectations and the altruism dummy is smaller than that of the coefficient of inheritance expectations when entered in isolation, while that of the coefficient of the interactive term between inheritance expectations and the exchange motive dummy is larger. The former is statistically significant at the $10 \%$ level, and the latter is statistically significant at the $5 \%$ level. Second, inheritance experience has a positive impact. Third, filial income has a negative impact. On the other hand, the impact of the presence of grandchildren is negative and statistically insignificant, while the impact of the presence of grandchildren living apart from children is positive and statistically significant. These findings thereon are hostile to the demonstration effect.

\section{Robustness Checks}

Table 10 shows the robustness checks of the results in Table 5 concerning co-residence. The signs of the coefficients for the ten subsamples, as shown in columns 2 through 11, are approximately 
the same as those for the full sample, as shown in column $1 .{ }^{18}$ The relative magnitude of the coefficients of inheritance expectations is also roughly the same even if observations that live far from both their parents and in-laws are excluded, as shown in columns 4 through 6 , and even when the sample is confined to those are forty and older, as shown in column 9, but different between males and females, which can be seen by comparing columns 2 and 3, columns 7 and 8 , and columns 10 and 11. In columns 2 and 7, which show the results for the male subsample, the impact of inheritance expectations is approximately the same in the case of altruistic individuals as in the case of those with an exchange motive, and in column 10, which shows the result for the forty and older subsample of males, the impact of inheritance expectations is greater in the case of altruistic individuals than in the case of those with an exchange motive. By contrast, in columns 3 and 8, which show the results for the female subsample, the impact of inheritance expectations is far greater in the case of those with an exchange motive than in the case of altruistic individuals, and in column 11, which shows the result for the forty and older subsample of females, the inheritance expectations is statistically significant in the case of those who with an exchange motive but not in the case of altruistic individuals. These results suggest that males respond similarly to the threat of disinheritance whether they are altruistic or strategic and that strategic females respond to the threat of disinheritance more than twice as strongly as altruistic females do.

Table 11 shows the robustness checks of the results in Table 6 concerning distance between the respondent's residence and the parents who live closer to respondent. When the sample is stratified by gender, inheritance experience has a statistically significant impact on the frequency of contact in the female subsample, as shown in columns 3 and 11, but not in the male subsample, as shown in columns 2, 6, and 10 .

Table 12 shows the robustness checks for the results in Table 7 concerning distance between the respondent's residence and that of the husband's parents. The impact of inheritance experience remains positive and statistically significant in various subsamples, and the impact of inheritance expectations remains positive and statistically significant in the case of those with an exchange motive even when respondents who live far from their parents and in-laws are excluded or when respondents who live close to their parents or in-laws are excluded as shown in columns 4,5 , and 8. When the sample is stratified by gender, the impact of inheritance expectations is statistically significant in the case of those with an exchange motive but not in the case of altruistic individuals

\footnotetext{
${ }^{18}$ The impact of income remains statistically significant in the male subsample but not in the female subsample.
} 
in the female subsamples, as shown in columns 3,7 , and 11 , whereas it is positive but statistically insignificant in the male subsamples, as shown in columns 2, 6, and 10.

Table 13 shows the robustness checks for the results in Table 8 concerning the frequency of contact with parents or in-laws. The impact of inheritance experience remains positive and statistically significant in various subsamples. The impact of expected inheritance experience is positive and statistically significant in the male subsamples as shown in columns 2,6 , and 10 , which favors the exchange motive.

Table 14 shows the robustness checks for the results in Table 9 concerning contact with the husband's parents. The impact of inheritance experience remains positive and statistically significant in various subsamples, and the impact of inheritance expectations remains positive and statistically significant in the case of those with an exchange motive even when respondents who live far from their parents and in-laws are excluded or when respondents who live close to their parents or in-laws are excluded as shown in columns 4, 5, 8, and 9. When the sample is stratified by gender, the impact of inheritance expectations is statistically significant in the case of those with an exchange motive but not in the case of altruistic individuals in the female subsamples, as shown in columns 3, 7, and 11, whereas it is positive but statistically insignificant in the male subsamples, as shown in columns 2, 6, and 10. Conversely, the impact of inheritance expectations is positive and statistically significant in the case of altruistic individuals but not in the case of those with an exchange motive in the forty and older subsample, as shown in column 12, which favors mutual altruism. The impact of inheritance experience and that of expected parental assistance is positive and statistically significant in the male subsamples as shown in columns 2, 6, and 10 .

As we seen in Tables 10 through 14, the impact of inheritance expectations is greater and statistically more significant in the case of those with an exchange motive than in the case of altruistic individuals in the female subsamples whereas the opposite result is obtained in the male subsamples, regardless of the dependent variable used. Three interpretations of these results are possible. First, the simplest interpretation is that females behave more strategically than males do. Second, it could be that females have greater expectations of receiving a return from their parentsin-law than males do since in Japan it is typically the daughter-in-law who plays a central role in the care of parents. My results might be consistent with the strategic bequest motive. Finally, married men tend to co-reside with their own parents whereas married women tend to co-reside with their 
parents-in-law. ${ }^{19}$ It is more natural for individuals to provide attention to their own parents as compared to their parents-in-law, either simply because children are more likely to harbor altruistic feelings toward their own parents or because children are more indebted to their own parents. If so, the exchange model should be more likely to apply to females in a patrilineal society such as Japan. Note, however, that the decision about how much attention to provide to one's parents is made not by individuals but by couples, and thus one's parent's threat of disinheritance should be effective for husbands through bargaining between couples.

\section{E. Summary}

I obtain several kinds of evidence in support of the exchange motive in my analysis of co-residence, and the results are robust, holding for the full sample as well as for various subsamples. Inheritance expectations affect the probability of co-residence, after filial altruism has been controlled for, even in the subsample confined to those who live within walking distance of their parents or in-laws. I also obtain several kinds of evidence in support of the exchange motive in my analysis of distance and contact even if respondents who co-reside with parents or in-laws are excluded, and the results are robust, holding for most subsamples. Inheritance expectations and inheritance experience affect the distance between residences as well as the frequency of contact. In the forty and older subsample of females, the impact of inheritance expectations on co-residence is greater and highly significant in the case of those who with an exchange motive but negative and insignificant in the case of altruistic individuals. As discussed above, the difference between the results for the male and female subsamples can be also interpreted as being consistent with the exchange motive. No support is found for the demonstration effect in my analyses of co-residence, distance, and contact.

\section{Concluding Remarks}

In this paper, I find that intergenerational co-residence, distance between residences, and frequency of contact is consistent with the exchange motive. These findings seem to be at variance with common sense: the Japanese often feel guilty about not living with their parents, and intergenerational co-residence is regarded as a virtue in terms of traditional morals persisting in Japan. Expressed

\footnotetext{
${ }^{19}$ Among males who co-reside with their parents or in-laws, $80 \%$ males co-reside with their own parents, $28 \%$ males co-reside with their parents-in-law, and $8 \%$ males co-reside with both their parents and in-laws. On the contrary, among females who co-reside with their parents or in-laws, $28 \%$ females co-reside with their own parents, $80 \%$ females co-reside with their parents-in-law, and $8 \%$ females co-reside with both their parents and in-laws.
} 
in another way, co-residence arising from the exchange motive is, in effect, a system of reciprocal assistance. ${ }^{20}$ Exchange within families involves a strict enforcement mechanism, and the far-sighted rationality that the demonstration effect requires is probably unreasonable. Inasmuch as intrafamily transfers from children to parents are based not on altruism but on an exchange motive, the Samaritan's dilemma does not arise - that is, the elderly do not undersave stemming from the expectation of receiving financial assistance from their altruistic children in old age. The high saving rate, especially of the elderly, in Japan is consistent with this interpretation.

Japan's social security is essentially a pay-as-you-go system, which entails unilateral upstream income redistribution. Its structure is parallel to the demonstration effect. At present, a large number of people do not contribute to the public pension system, and this problem is becoming severe. This suggests that the demonstration effect does not apply to household behavior in Japan. In the case of the demonstration effect, public income redistributions from younger to older generations such as a pay-as-you-go social security system or a long-term care insurance system will crowd out intra-family transfers since individuals can receive public assistance in old age even if they do not provide attention to their parents. However, in the case of the exchange motive, the introduction or reinforcement of such public income redistribution systems will not crowd out intra-family transfers in the short term. A pay-as-you-go social security system should not affect children's behavior since social security benefits are not a bequeathable asset.

\section{References}

Altonji, J. G., Hayashi, F., Kotlikoff, L. J., "Is the Extended Family Altruistically Linked? Direct Tests Using Micro Data," American Economic Review, Vol. 82, No. 5 (December, 1992), 11771198.

Altonji, J. G., Hayashi, F., Kotlikoff, L. J., "The Effects of Income and Wealth on Time and Money Transfers between Parents and Children," National Bureau of Economic Research Working Paper, No. 5522 (April, 1996).

\footnotetext{
${ }^{20}$ Fehr and Gächter (2000, page 160, line 33) state that "Reciprocity is fundamentally different from "cooperative" or "retaliatory" behavior in repeated interactions. These behaviors arise because actors expect future material benefits from their actions; in the case of reciprocity the actor is responding to friendly or hostile actions even if no material gains can be expected. Reciprocity is also fundamentally different from altruism. Altruism is a form of unconditional kindness; that is altruism given does not emerge as a response to altruism received. Again, reciprocity is an in-kind response to beneficial or harmful acts."
} 
Barro, R. J., "Are Government Bonds Net Wealth," Journal of Political Economy, Vol. 82, No. 6 (November/December, 1974), 1095-1117.

Barthold, T. A., Ito, T., "Bequest Taxes and Accumulation of Household Wealth: U.S.-Japan Comparison," edited by Takatoshi Ito and Anne O. Krueger, The Political Economy of Tax Reform. NBER-East Asia Seminar on Economics, Vol. 1 (Chicago and London: University of Chicago Press, 1992), 235-90.

Becker, G. S., "A Theory of Social Interactions," Journal of Political Economy, Vol. 82, No. 6 (November/December, 1974), 1063-1076.

Becker, G. S., Murphy, K. M., Social Economics: Market Behavior in a Social Environment, (Cambridge, Massachusetts: Harvard University Press, 2000).

Bernheim, B. D., Shleifer, A., Summers, L. H., "The Strategic Bequest Motive," Journal of Political Economy, Vol. 93, No. 6 (December, 1985), 1045-1176.

Cho, L-J, Yada, M., Tradition and Change in the Asian Family (Honolulu: East-West Center, 1994).

Cox, D, "Motives for Private Income Transfers", Journal of Political Economy, Vol. 95, No. 3 (June, 1987), 508-546.

Cox, D, Rank, M. R., "Inter-Vivos Transfers and Intergenerational Exchange," Review of Economics and Statistics, Vol. 74, No. 2 (May, 1992), 305-314.

Cox, D., Stark, O., "An Exchange Implication of Transfers: The Demonstration Effect," in Oded Stark, Altruism and Beyond: An Economic Analysis of Transfers and Exchanges within Families and Groups (Oscar Morgenstern Memorial Lectures), (Cambridge, the United Kingdom: Cambridge University Press, 1995), 48-85.

Fehr, E., Gächter, S., "Fairness and Retaliation: The Economics of Reciprocity," Journal of Economic Perspectives, Vol. 14, No. 3 (Summer, 2000), 159-181.

Hayashi, F., "Is the Japanese Extended Family Altruistically Linked? A Test based on Engel Curves," in Fumio Hayashi, Understanding saving: Evidence from the United States and Japan (Cambridge and London: MIT Press, 1997), 209-239. 
Horioka, C. Y., "Are the Japanese Selfish, Altruistic, or Dynastic?," Japanese Economic Review, Vol. 53, No. 1 (March, 2002), 26-54.

Institute for Posts and Telecommunications Policy, "Chochiku ni kansuru Nichibei Hikaku Chousa, (The Comparative Survey on Saving in Japan and the United States)," (Tokyo: Institute for Posts and Telecommunications Policy, Ministry of Posts and Telecommunications, 1997) (in Japanese).

Jellal, M., Wolff, F. C., "Shaping Intergenerational Relationships: The Demonstration Effect," Economics Letters, Vol. 68, No. 3 (September, 2000), 255-261.

Joulfaian, D, Wilhelm, M. O., "Inheritance and Labor Supply," Journal of Human Resources, Vol. 29, No.4 (Fall, 1994), 1205-1234.

Mason, K. O., Tsuya, O. N., Choe, M. K., The Changing Family in Comparative Perspective: Asia and the United States (Honolulu: East-West Center, 1998).

Noguchi, Y., "Kazoku-nai no Sedai-kan Iten: Kyojuuyou-Zaisan no Souzoku wo Chuushin toshite (Intergenerational Transfers within Families: With Emphasis on Inheritances of Residential Properties)," JCER Economic Journal, No. 22 (March, 1992), 166-189.

Office for Policy on the Aging of Society, "Koureisha no Seikatsu to Ishiki: Daiyonkai Kokusai Hikaku Chousa Kekka Houkokusho (The Lives and Attitudes of the Elderly: The Report on the Fourth International Comparative Survey)," (Tokyo: Chuuou Houki Shuppan, 1997) (in Japanese).

Ohtake, F., Horioka, C. Y., "Chochiku Douki (Saving Motives)," edited by Tsuneo Ishikawa, Nihon no Shotoku to Tomi no Bunpai (The Distribution of Income and Wealth in Japan), (Tokyo: The University of Tokyo Press, 1994), 211-244 (in Japanese).

Perozek, M. G., "Comment: A Reexamination of the Strategic Bequest Motive," Journal of Political Economy, Vol. 106, No. 2 (April, 1998), 423-445.

Wolff, F. C., "Private Intergenerational Contact in France and the Demonstration Effect," Applied Economics, Vol. 33, No. 2 (February, 2001), 143-153. 
Table 1

Variable Definitions

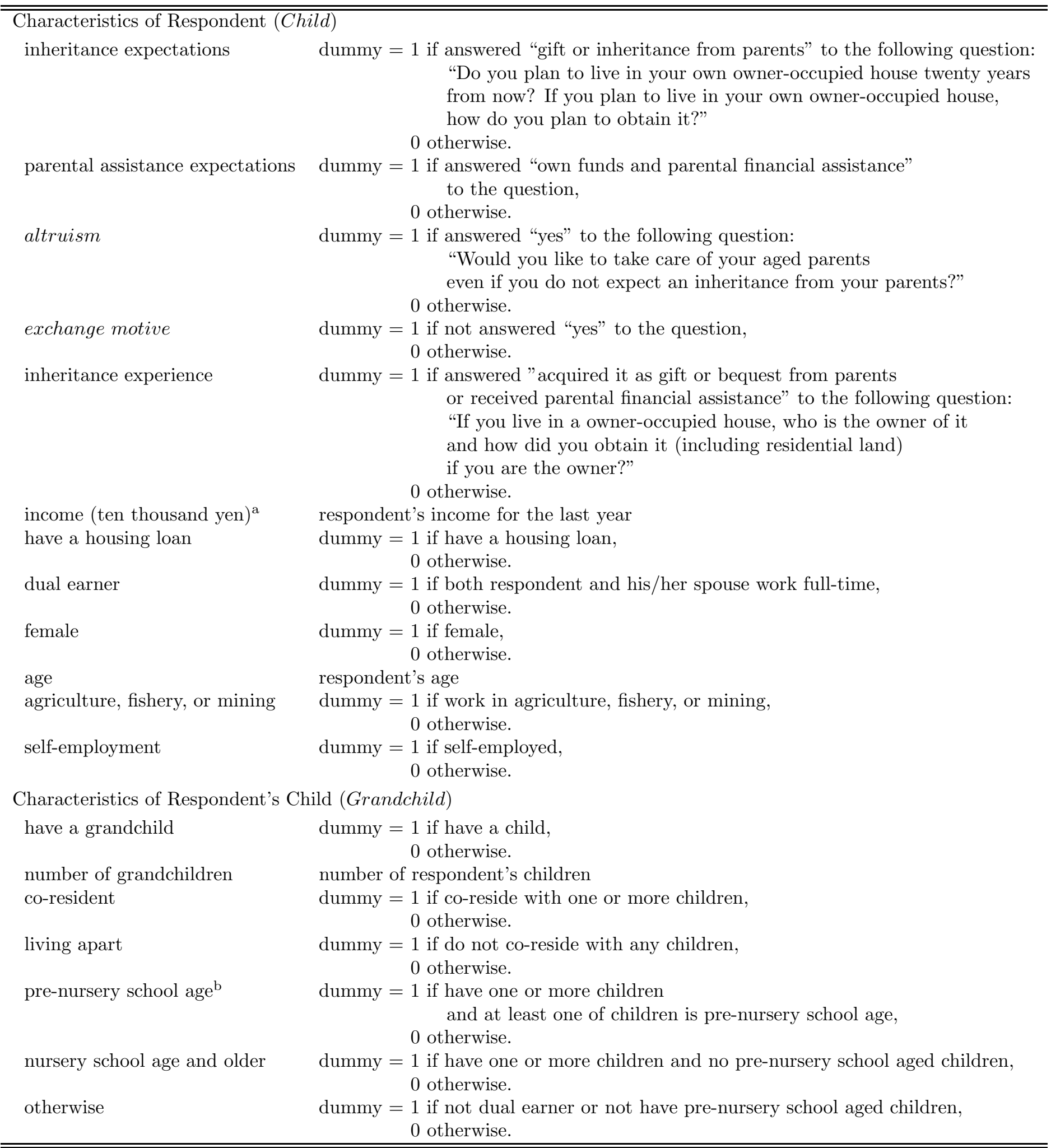

a 1 dollar = 126.84 yen in June, 1992.

b In Japan, the academic year starts in April and children who are at least three years old on April 1 are eligible to enter nursery school starting from that academic year. 
Table 2

Sample Means

\begin{tabular}{lccc}
\hline \hline Variables & Full Sample & Married & Unmarried \\
\hline inheritance expectations & 0.184 & 0.163 & 0.255 \\
altruism & 0.321 & 0.319 & 0.327 \\
exchange motive & 0.679 & 0.681 & 0.673 \\
(inheritance expectations) $\times($ altruism) & 0.059 & 0.053 & 0.082 \\
(inheritance expectations) $\times($ exchange motive) & 0.124 & 0.110 & 0.172 \\
inheritance experience & 0.103 & 0.126 & 0.021 \\
parental assistance expectations & 0.134 & 0.124 & 0.169 \\
have a grandchild & 0.701 & 0.908 & - \\
number of grandchildren & 1.458 & 1.888 & - \\
(have a grandchild) $\times$ (co-resident) & 0.656 & 0.850 & - \\
(have a grandchild) $\times$ (living apart) & 0.045 & 0.058 & - \\
(have a grandchild) $\times$ (pre-nursery school age) & 0.216 & 0.279 & - \\
(have a grandchild) $\times$ (nursery school age and older) & 0.485 & 0.628 & - \\
(have a grandchild) $\times$ (pre-nursery school age) & 0.038 & 0.049 & - \\
$\times$ (dual earner) & & & \\
(have a grandchild) $\times$ (otherwise) & 0.663 & 0.858 & - \\
income (ten thousand yen) & 314.2 & 334.5 & 245.1 \\
have a housing loan & 0.295 & 0.335 & 0.161 \\
dual earner & 0.224 & 0.290 & 0 \\
female & 0.532 & 0.537 & 0.514 \\
age & 36.46 & 39.27 & 26.91 \\
married & 0.772 & 1 & 0 \\
self-employment & 0.096 & 0.099 & 0.086 \\
agriculture, fishery, or mining & 0.028 & 0.030 & 0.021 \\
co-residence with parents or parents-in-law & 0.434 & 0.302 & 0.884 \\
Number of Observations & 1221 & 943 & 278 \\
\hline \hline
\end{tabular}

The raw data of the SLPALL has 2,804 observations. I select the sample that I use in my analysis in six stages. First, after eliminating observations that have missing values, 1,602 observations remain. Second, after eliminating observations that have inconsistent responses, 1,557 observations remain. The SLPALL asks several questions about the respondent's parents and children, and 45 respondents did not answer the questions about the presence and number of children, about marital status and parents-in-law, and about whether or not their parents are alive without contradiction. Third, after eliminating the unemployed, 1,513 observations remain. Fourth, after eliminating the respondents both of whose parents have passed away, 1,379 observations remain. Fifth, after eliminating the respondents both of whose parents-in-law have passed away, 1,231 remain. Finally, after eliminating the divorced, 1,221 observations remain. 
Table 3

Sample Means for Married Respondents

\begin{tabular}{lcc}
\hline \hline Variables & Co-residence & Living Apart \\
\hline inheritance expectations & 0.333 & 0.089 \\
altruism & 0.302 & 0.327 \\
exchange motive & 0.698 & 0.673 \\
(inheritance expectations) $\times($ altruism $)$ & 0.091 & 0.036 \\
(inheritance expectations) $\times($ exchange motive) & 0.242 & 0.053 \\
inheritance experience & 0.154 & 0.113 \\
parental assistance expectations & 0.084 & 0.141 \\
have a grandchild & 0.947 & 0.892 \\
number of grandchildren & 2.094 & 1.799 \\
(have a grandchild) $\times($ co-resident) & 0.880 & 0.837 \\
(have a grandchild) $\times($ living apart) & 0.066 & 0.054 \\
(have a grandchild) $\times$ (pre-nursery school age) & 0.256 & 0.290 \\
(have a grandchild) $\times$ (nursery school age and older) & 0.691 & 0.601 \\
(have a grandchild) $\times$ (pre-nursery school age) & 0.084 & 0.034 \\
$\times$ (dual earner) & & \\
(have a grandchild) $\times$ (otherwise) & 0.863 & 0.857 \\
income & 338.1 & 332.9 \\
have a housing loan & 0.389 & 0.311 \\
dual earner & 0.421 & 0.234 \\
female & 0.519 & 0.545 \\
age & 41.05 & 38.51 \\
agriculture, fishery, or mining & 0.066 & 0.015 \\
self-employment & 0.101 & 0.098 \\
Number of Observations & 285 & 658 \\
\hline \hline Colym
\end{tabular}

Column 1 shows the variable means of married respondents who co-reside with their parents or parents-in-law. Column 2 shows the variable means of married respondents who live apart from both parents and in-laws. 
Table 4

Summary Statistics of Dependent Variables

\begin{tabular}{|c|c|c|c|c|}
\hline Variables & Mean & $\begin{array}{l}\text { Standard } \\
\text { Deviation }\end{array}$ & Minimum & Maximum \\
\hline \multicolumn{5}{|l|}{ Co-residence } \\
\hline with parents & 0.160 & 0.366 & 0 & 1 \\
\hline with parents-in-law & 0.167 & 0.373 & 0 & 1 \\
\hline with husband's parents & 0.241 & 0.428 & 0 & 1 \\
\hline with wife's parents & 0.085 & 0.280 & 0 & 1 \\
\hline with parents or parents-in-law & 0.302 & 0.459 & 0 & 1 \\
\hline \multicolumn{5}{|c|}{ Number of Observations: 943} \\
\hline \multicolumn{5}{|c|}{ Distance between Residences } \\
\hline of parents & 2.496 & 1.053 & 1 & 5 \\
\hline of parents-in-law & 2.504 & 1.028 & 1 & 5 \\
\hline of husband's parents & 2.545 & 1.073 & 1 & 5 \\
\hline of wife's parents & 2.455 & 1.004 & 1 & 5 \\
\hline of parents who live closer & 2.562 & 1.058 & 1 & 5 \\
\hline \multicolumn{5}{|l|}{ Frequency of Contact } \\
\hline with parents & 53.04 & 85.53 & 0 & 300 \\
\hline with parents-in-law & 32.05 & 62.67 & 0 & 300 \\
\hline with husband's parents & 41.00 & 74.98 & 0 & 300 \\
\hline with wife's parents & 44.09 & 76.40 & 0 & 300 \\
\hline with parents or parents-in-law & 85.09 & 112.61 & 0 & 600 \\
\hline \multicolumn{5}{|c|}{ Number of Observations: 658} \\
\hline
\end{tabular}

I analyze the determinants of co-residence using the sample of married respondents and the determinants of distance between residences and the frequency of contact using the sample of married respondents who live apart from both their parents and in-laws. 
Table 5

Marginal Effects on the Probability of Co-residence with Parents or Parents-in-Law

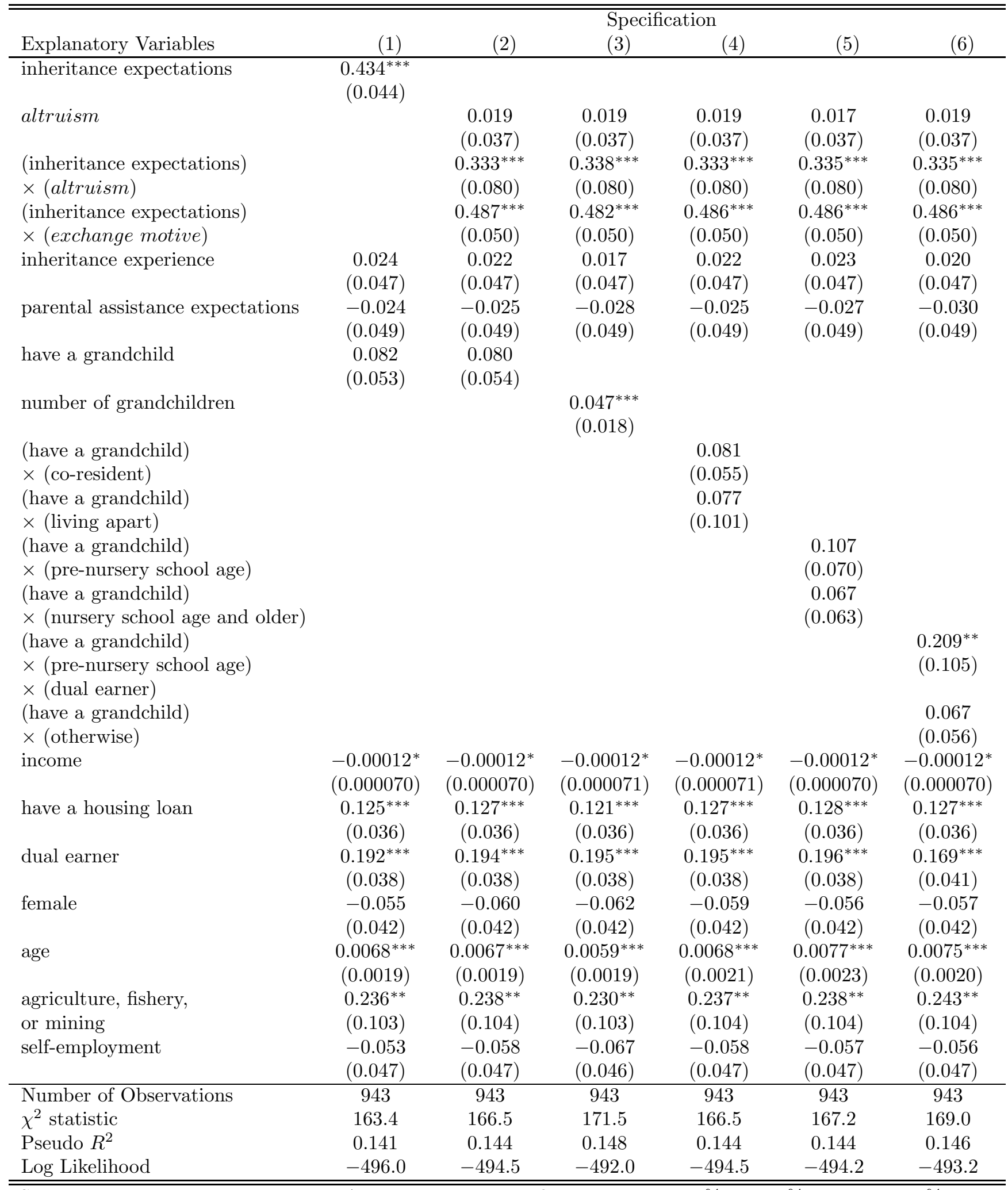

Standard errors are in parentheses. Asterisks denote significant levels: $* 10 \%, * * 5 \%$, and $* * * 1 \%$. The $\chi^{2}$ statistic denotes the $\chi^{2}$ statistic for the null hypothesis that all coefficients excluding the intercept are zero. These notes also apply to Tables 7 through 15 . 
Table 6

Determinants of Distance between Respondent's Residence and That of Parents Who Live Closer to Respondent

\begin{tabular}{|c|c|c|c|c|c|c|}
\hline \multirow[b]{2}{*}{ Explanatory Variables } & \multicolumn{6}{|c|}{ Specification } \\
\hline & (1) & $(2)$ & $(3)$ & (4) & (5) & (6) \\
\hline inheritance expectations & $\begin{array}{l}0.291^{*} \\
(0.151)\end{array}$ & & & & & \\
\hline altruism & & $\begin{array}{l}-0.047 \\
(0.094)\end{array}$ & $\begin{array}{l}-0.047 \\
(0.094)\end{array}$ & $\begin{array}{l}-0.044 \\
(0.094)\end{array}$ & $\begin{array}{l}-0.037 \\
(0.095)\end{array}$ & $\begin{array}{l}-0.045 \\
(0.095)\end{array}$ \\
\hline (inheritance expectations) & & 0.332 & 0.328 & 0.326 & 0.330 & 0.329 \\
\hline$\times($ altruism $)$ & & $(0.234)$ & $(0.234)$ & $(0.234)$ & $(0.234)$ & $(0.234)$ \\
\hline (inheritance expectations) & & 0.270 & 0.270 & 0.299 & 0.276 & 0.270 \\
\hline$\times($ exchange motive $)$ & & $(0.194)$ & $(0.194)$ & $(0.194)$ & $(0.194)$ & $(0.194)$ \\
\hline inheritance experience & $\begin{array}{l}0.278^{* *} \\
(0.136)\end{array}$ & $\begin{array}{l}0.278^{* *} \\
(0.136)\end{array}$ & $\begin{array}{l}0.278^{* *} \\
(0.136)\end{array}$ & $\begin{array}{l}0.272^{* *} \\
(0.136)\end{array}$ & $\begin{array}{l}0.274^{* *} \\
(0.136)\end{array}$ & $\begin{array}{l}0.279^{* *} \\
(0.136)\end{array}$ \\
\hline parental assistance expectations & $\begin{array}{l}-0.027 \\
(0.123)\end{array}$ & $\begin{array}{l}-0.024 \\
(0.123)\end{array}$ & $\begin{array}{l}-0.024 \\
(0.123)\end{array}$ & $\begin{array}{l}-0.023 \\
(0.123)\end{array}$ & $\begin{array}{l}-0.020 \\
(0.124)\end{array}$ & $\begin{array}{l}-0.024 \\
(0.123)\end{array}$ \\
\hline have a grandchild & $\begin{array}{l}-0.031 \\
(0.141)\end{array}$ & $\begin{array}{l}-0.030 \\
(0.141)\end{array}$ & & & & \\
\hline number of grandchildren & & & $\begin{array}{l}-0.021 \\
(0.047)\end{array}$ & & & \\
\hline (have a grandchild) & & & & -0.032 & & \\
\hline$\times($ co-resident $)$ & & & & $(0.142)$ & & \\
\hline (have a grandchild) & & & & 0.474 & & \\
\hline$\times$ (living apart) & & & & $(0.243)$ & & \\
\hline (have a grandchild) & & & & & -0.085 & \\
\hline$\times($ pre-nursery school age $)$ & & & & & $(0.150)$ & \\
\hline (have a grandchild) & & & & & 0.040 & \\
\hline$\times($ nursery school age and older $)$ & & & & & $(0.156)$ & \\
\hline (have a grandchild) & & & & & & -0.099 \\
\hline $\begin{array}{l}\times(\text { pre-nursery school age }) \\
\times(\text { dual earner })\end{array}$ & & & & & & $(0.267)$ \\
\hline $\begin{array}{l}\text { (have a grandchild) } \\
\times \text { (otherwise) }\end{array}$ & & & & & & $\begin{array}{l}-0.023 \\
(0.143)\end{array}$ \\
\hline income & $\begin{array}{l}-0.00023 \\
(0.00019)\end{array}$ & $\begin{array}{l}-0.00025 \\
(0.00019)\end{array}$ & $\begin{array}{l}-0.00024 \\
(0.00019)\end{array}$ & $\begin{array}{l}-0.00024 \\
(0.00019)\end{array}$ & $\begin{array}{l}-0.00024 \\
(0.00019)\end{array}$ & $\begin{array}{l}-0.00025 \\
(0.00019)\end{array}$ \\
\hline have a housing loan & $\begin{array}{c}0.148 \\
(0.096)\end{array}$ & $\begin{array}{c}0.147 \\
(0.096)\end{array}$ & $\begin{array}{c}0.151 \\
(0.096)\end{array}$ & $\begin{array}{c}0.173 \\
(0.097)\end{array}$ & $\begin{array}{c}0.141 \\
(0.096)\end{array}$ & $\begin{array}{c}0.148 \\
(0.096)\end{array}$ \\
\hline dual earner & $\begin{array}{c}0.257^{* *} \\
(0.107)\end{array}$ & $\begin{array}{l}0.255^{* *} \\
(0.107)\end{array}$ & $\begin{array}{l}0.251^{* *} \\
(0.108)\end{array}$ & $\begin{array}{c}0.243^{* *} \\
(0.108)\end{array}$ & $\begin{array}{c}0.246^{* *} \\
(0.108)\end{array}$ & $\begin{array}{l}0.268^{* *} \\
(0.115)\end{array}$ \\
\hline female & $\begin{array}{c}0.826^{* * *} \\
(0.119)\end{array}$ & $\begin{array}{c}0.824^{* * *} \\
(0.119)\end{array}$ & $\begin{array}{c}0.827^{* * *} \\
(0.119)\end{array}$ & $\begin{array}{c}0.820^{* * *} \\
(0.119)\end{array}$ & $\begin{array}{c}0.809^{* * *} \\
(0.120)\end{array}$ & $\begin{array}{c}0.822^{* * *} \\
(0.119)\end{array}$ \\
\hline age & $\begin{array}{l}-0.0083 \\
(0.0053)\end{array}$ & $\begin{array}{l}-0.0083 \\
(0.0053)\end{array}$ & $\begin{array}{l}-0.0079 \\
(0.0054)\end{array}$ & $\begin{array}{l}-0.013 \\
(0.0057)\end{array}$ & $\begin{array}{c}-0.011 \\
(0.0063)\end{array}$ & $\begin{array}{l}-0.0086 \\
(0.0054)\end{array}$ \\
\hline $\begin{array}{l}\text { agriculture, fishery, } \\
\text { or mining }\end{array}$ & $\begin{array}{l}-0.139 \\
(0.364)\end{array}$ & $\begin{array}{l}-0.148 \\
(0.364)\end{array}$ & $\begin{array}{l}-0.136 \\
(0.366)\end{array}$ & $\begin{array}{l}-0.139 \\
(0.365)\end{array}$ & $\begin{array}{l}-0.149 \\
(0.364)\end{array}$ & $\begin{array}{l}-0.151 \\
(0.364)\end{array}$ \\
\hline self-employment & $\begin{array}{l}0.344^{* *} \\
(0.150)\end{array}$ & $\begin{array}{l}0.345^{* *} \\
(0.150)\end{array}$ & $\begin{array}{l}0.354^{* *} \\
(0.152)\end{array}$ & $\begin{array}{l}0.335^{* *} \\
(0.151)\end{array}$ & $\begin{array}{l}0.345^{* *} \\
(0.150)\end{array}$ & $\begin{array}{l}0.345^{* *} \\
(0.150)\end{array}$ \\
\hline Number of Observations & 658 & 658 & 658 & 658 & 658 & 658 \\
\hline$\chi^{2}$ statistic & 143.4 & 143.7 & 143.8 & 150.2 & 144.8 & 143.8 \\
\hline Pseudo $R^{2}$ & 0.076 & 0.076 & 0.076 & 0.080 & 0.077 & 0.076 \\
\hline Log Likelihood & -865.6 & -865.5 & -865.4 & -862.2 & -864.9 & -865.4 \\
\hline
\end{tabular}


Table 7

Determinants of Distance between Respondent's Residence and That of the Husband's Parents

\begin{tabular}{|c|c|c|c|c|c|c|}
\hline Explanatory Variables & $(1)$ & $(2)$ & $\begin{array}{l}\text { Specifi } \\
(3)\end{array}$ & ation & $(5)$ & $(6)$ \\
\hline inheritance expectations & $\begin{array}{c}0.460^{* * *} \\
(0.149)\end{array}$ & & & & & \\
\hline altruism & & $\begin{array}{l}-0.069 \\
(0.094)\end{array}$ & $\begin{array}{l}-0.068 \\
(0.094)\end{array}$ & $\begin{array}{l}-0.067 \\
(0.094)\end{array}$ & $\begin{array}{l}-0.056 \\
(0.094)\end{array}$ & $\begin{array}{l}-0.065 \\
(0.094)\end{array}$ \\
\hline (inheritance expectations) & & $0.438^{*}$ & $0.441^{*}$ & $0.433^{*}$ & $0.435^{*}$ & $0.432^{*}$ \\
\hline$\times($ altruism $)$ & & $(0.232)$ & $(0.232)$ & $(0.232)$ & $(0.232)$ & $(0.232)$ \\
\hline (inheritance expectations) & & $0.488^{* * *}$ & $0.494^{* * *}$ & $0.516^{* * *}$ & $0.498^{* * *}$ & $0.488^{* * *}$ \\
\hline$\times($ exchange motive $)$ & & $(0.190)$ & $(0.190)$ & $(0.191)$ & $(0.190)$ & $(0.190)$ \\
\hline inheritance experience & $\begin{array}{c}0.452^{* * *} \\
(0.134)\end{array}$ & $\begin{array}{c}0.447^{* * *} \\
(0.134)\end{array}$ & $\begin{array}{c}0.449^{* * *} \\
(0.134)\end{array}$ & $\begin{array}{c}0.444^{* * *} \\
(0.134)\end{array}$ & $\begin{array}{c}0.442^{* * *} \\
(0.134)\end{array}$ & $\begin{array}{c}0.449^{* * *} \\
(0.134)\end{array}$ \\
\hline parental assistance expectations & $\begin{array}{l}0.0077 \\
(0.123)\end{array}$ & $\begin{array}{c}0.012 \\
(0.123)\end{array}$ & $\begin{array}{c}0.014 \\
(0.122)\end{array}$ & $\begin{array}{c}0.013 \\
(0.123)\end{array}$ & $\begin{array}{c}0.017 \\
(0.123)\end{array}$ & $\begin{array}{c}0.013 \\
(0.123)\end{array}$ \\
\hline have a grandchild & $\begin{array}{c}0.105 \\
(0.140)\end{array}$ & $\begin{array}{c}0.104 \\
(0.141)\end{array}$ & & & & \\
\hline number of grandchildren & & & $\begin{array}{c}0.019 \\
(0.047)\end{array}$ & & & \\
\hline (have a grandchild) & & & & 0.103 & & \\
\hline$\times($ co-resident $)$ & & & & $(0.141)$ & & \\
\hline (have a grandchild) & & & & 0.602 & & \\
\hline$\times$ (living apart) & & & & $(0.241)$ & & \\
\hline (have a grandchild) & & & & & 0.029 & \\
\hline$\times$ (pre-nursery school age) & & & & & $(0.150)$ & \\
\hline (have a grandchild) & & & & & 0.201 & \\
\hline$\times($ nursery school age and older $)$ & & & & & $(0.155)$ & \\
\hline (have a grandchild) & & & & & & -0.025 \\
\hline$\times($ pre-nursery school age) & & & & & & $(0.266)$ \\
\hline \multicolumn{7}{|l|}{$\times($ dual earner $)$} \\
\hline \multirow{2}{*}{$\begin{array}{l}\text { (have a grandchild) } \\
\times(\text { otherwise })\end{array}$} & & & & & & 0.116 \\
\hline & & & & & & $(0.142)$ \\
\hline \multirow[t]{2}{*}{ income } & $-0.00036^{*}$ & $-0.00038^{*}$ & $-0.00039^{* *}$ & $-0.00038^{*}$ & $-0.00038^{*}$ & $-0.00038^{*}$ \\
\hline & $(0.00019)$ & $(0.00019)$ & $(0.00019)$ & $(0.00019)$ & $(0.00019)$ & $(0.00019)$ \\
\hline \multirow[t]{2}{*}{ have a housing loan } & 0.113 & 0.113 & 0.116 & 0.138 & 0.105 & 0.114 \\
\hline & $(0.095)$ & $(0.095)$ & $(0.095)$ & $(0.096)$ & $(0.095)$ & $(0.095)$ \\
\hline \multirow[t]{2}{*}{ dual earner } & $0.285^{* * *}$ & $0.282^{* * *}$ & $0.279^{* * *}$ & $0.269^{* * *}$ & $0.269^{* * *}$ & $0.305^{* * *}$ \\
\hline & $(0.106)$ & $(0.106)$ & $(0.107)$ & $(0.107)$ & $(0.107)$ & $(0.114)$ \\
\hline \multirow[t]{2}{*}{ female } & -0.057 & -0.060 & -0.056 & -0.069 & -0.082 & -0.064 \\
\hline & $(0.116)$ & $(0.116)$ & $(0.116)$ & $(0.116)$ & $(0.117)$ & $(0.116)$ \\
\hline \multirow[t]{2}{*}{ age } & -0.0070 & -0.0069 & -0.0065 & -0.011 & -0.012 & -0.0075 \\
\hline & $(0.0053)$ & $(0.0053)$ & $(0.0053)$ & $(0.0056)$ & $(0.0063)$ & $(0.0054)$ \\
\hline \multirow{4}{*}{$\begin{array}{l}\text { agriculture, fishery, } \\
\text { or mining } \\
\text { self-employment }\end{array}$} & 0.481 & 0.468 & 0.465 & 0.479 & 0.467 & 0.461 \\
\hline & $(0.345)$ & $(0.346)$ & $(0.347)$ & $(0.346)$ & $(0.346)$ & $(0.346)$ \\
\hline & $0.470^{* * *}$ & $0.467^{* * *}$ & $0.460^{* * *}$ & $0.459^{* * *}$ & $0.466^{* * *}$ & $0.466^{* * *}$ \\
\hline & $(0.148)$ & $(0.148)$ & $(0.150)$ & $(0.149)$ & $(0.148)$ & $(0.148)$ \\
\hline Number of Observations & 658 & 658 & 658 & 658 & 658 & 658 \\
\hline$\chi^{2}$ statistic & 57.58 & 58.30 & 57.91 & 64.80 & 60.50 & 58.64 \\
\hline Pseudo $R^{2}$ & 0.030 & 0.030 & 0.030 & 0.034 & 0.031 & 0.031 \\
\hline Log Likelihood & -918.4 & -918.1 & -918.3 & -914.8 & -917.0 & -917.65 \\
\hline
\end{tabular}


Table 8

Determinants of Frequency of Contact with Parents or Parents-in-Law

\begin{tabular}{|c|c|c|c|c|c|c|}
\hline \multirow[b]{2}{*}{ Explanatory Variables } & \multicolumn{6}{|c|}{ Specification } \\
\hline & (1) & (2) & $(3)$ & $(4)$ & (5) & (6) \\
\hline inheritance expectations & $\begin{array}{c}20.52 \\
(15.37)\end{array}$ & & & & & \\
\hline altruism & & $\begin{array}{l}2.768 \\
(9.636)\end{array}$ & $\begin{array}{c}2.761 \\
(9.634)\end{array}$ & $\begin{array}{c}2.884 \\
(9.611)\end{array}$ & $\begin{array}{l}1.232 \\
(9.656)\end{array}$ & $\begin{array}{l}1.528 \\
(9.643)\end{array}$ \\
\hline (inheritance expectations) & & 13.85 & 13.41 & 13.26 & 14.38 & 15.68 \\
\hline$\times($ altruism $)$ & & $(23.89)$ & $(23.90)$ & $(23.83)$ & $(23.84)$ & $(23.86)$ \\
\hline $\begin{array}{l}\text { (inheritance expectations) } \\
\times(\text { exchange motive })\end{array}$ & & $\begin{array}{c}24.67 \\
(1960)\end{array}$ & $\begin{array}{c}24.48 \\
(19.58)\end{array}$ & $\begin{array}{c}26.60 \\
(19.58)\end{array}$ & $\begin{array}{l}23.69 \\
(1057)\end{array}$ & $\begin{array}{c}24.59 \\
(10.56)\end{array}$ \\
\hline $\begin{array}{l}\times(\text { exchange motive }) \\
\text { inheritance experience }\end{array}$ & $\begin{array}{c}42.63^{* * *} \\
(13.82)\end{array}$ & $\begin{array}{l}(19.60) \\
42.37^{* * *} \\
(13.86)\end{array}$ & $\begin{array}{c}(19.58) \\
42.37^{* * *} \\
(13.85)\end{array}$ & $\begin{array}{c}(19.58) \\
41.89^{* * *} \\
(13.82)\end{array}$ & $\begin{array}{c}(19.57) \\
43.08^{* * *} \\
(13.83)\end{array}$ & $\begin{array}{l}(19.56) \\
41.87^{* * *} \\
(13.83)\end{array}$ \\
\hline parental assistance expectations & $\begin{array}{c}7.689 \\
(12.62)\end{array}$ & $\begin{array}{l}7.480 \\
(12.64)\end{array}$ & $\begin{array}{c}7.431 \\
(12.63)\end{array}$ & $\begin{array}{c}7.626 \\
(12.60)\end{array}$ & $\begin{array}{c}6.768 \\
(12.61)\end{array}$ & $\begin{array}{c}6.865 \\
(12.61)\end{array}$ \\
\hline have a grandchild & $\begin{array}{l}-4.683 \\
(14.44)\end{array}$ & $\begin{array}{l}-4.877 \\
(14.45)\end{array}$ & & & & \\
\hline number of grandchildren & & & $\begin{array}{l}-2.403 \\
(4.850)\end{array}$ & & & \\
\hline (have a grandchild) & & & & -5.131 & & \\
\hline × (co-resident $)$ & & & & (14.41) & & \\
\hline (have a grandchild) & & & & 32.23 & & \\
\hline$\times$ (living apart) & & & & $(24.55)$ & & \\
\hline (have a grandchild) & & & & & 4.238 & \\
\hline$\times($ pre-nursery school age $)$ & & & & & $(15.35)$ & \\
\hline (have a grandchild) & & & & & -16.26 & \\
\hline × (nursery school age and older) & & & & & $(15.85)$ & \\
\hline (have a grandchild) & & & & & & 34.38 \\
\hline × (pre-nursery school age $)$ & & & & & & $(27.21)$ \\
\hline $\begin{array}{l}\times(\text { dual earner }) \\
(\text { have a grandchild }) \\
\times(\text { otherwise })\end{array}$ & & & & & & $\begin{array}{l}-8.445 \\
(14.57)\end{array}$ \\
\hline income & $\begin{array}{l}-0.024 \\
(0.019)\end{array}$ & $\begin{array}{l}-0.024 \\
(0.019)\end{array}$ & $\begin{array}{l}-0.023 \\
(0.019)\end{array}$ & $\begin{array}{l}-0.023 \\
(0.019)\end{array}$ & $\begin{array}{l}-0.024 \\
(0.019)\end{array}$ & $\begin{array}{l}-0.024 \\
(0.019)\end{array}$ \\
\hline have a housing loan & $\begin{array}{c}2.759 \\
(9.798)\end{array}$ & $\begin{array}{c}2.877 \\
(9.802)\end{array}$ & $\begin{array}{c}3.126 \\
(9.816)\end{array}$ & $\begin{array}{c}4.767 \\
(9.829)\end{array}$ & $\begin{array}{c}3.900 \\
(9.798)\end{array}$ & $\begin{array}{c}2.467 \\
(9.784)\end{array}$ \\
\hline dual earner & $\begin{array}{l}24.18^{* *} \\
(10.91)\end{array}$ & $\begin{array}{l}24.28^{* *} \\
(10.92)\end{array}$ & $\begin{array}{l}23.95^{* *} \\
(10.95)\end{array}$ & $\begin{array}{l}23.23^{* *} \\
(10.91)\end{array}$ & $\begin{array}{l}25.91^{* *} \\
(10.94)\end{array}$ & $\begin{array}{c}17.19 \\
(11.66)\end{array}$ \\
\hline female & $\begin{array}{c}19.53 \\
(11.91)\end{array}$ & $\begin{array}{c}19.64 \\
(11.92)\end{array}$ & $\begin{array}{l}19.87^{*} \\
(11.92)\end{array}$ & $\begin{array}{c}19.06 \\
(11.89)\end{array}$ & $\begin{array}{l}22.35^{*} \\
(11.99)\end{array}$ & $\begin{array}{l}20.54^{*} \\
(11.90)\end{array}$ \\
\hline age & $\begin{array}{l}-1.943^{* * *} \\
(0.544)\end{array}$ & $\begin{array}{l}-1.946^{* * *} \\
(0.544)\end{array}$ & $\begin{array}{l}-1.919^{* * *} \\
(0.547)\end{array}$ & $\begin{array}{c}-2.303^{* * *} \\
(0.575)\end{array}$ & $\begin{array}{c}-1.354^{* *} \\
(0.641)\end{array}$ & $\begin{array}{c}-1.777^{* * *} \\
(0.552)\end{array}$ \\
\hline $\begin{array}{l}\text { agriculture, fishery, } \\
\text { or mining }\end{array}$ & $\begin{array}{l}-9.438 \\
(35.50)\end{array}$ & $\begin{array}{l}-8.984 \\
(35.54)\end{array}$ & $\begin{array}{l}-7.701 \\
(35.70)\end{array}$ & $\begin{array}{l}-8.311 \\
(35.45)\end{array}$ & $\begin{array}{l}-8.915 \\
(35.47)\end{array}$ & $\begin{array}{l}-6.907 \\
(35.49)\end{array}$ \\
\hline self-employment & $\begin{array}{c}54.35^{* * *} \\
(15.25)\end{array}$ & $\begin{array}{c}54.07^{* * *} \\
(15.28)\end{array}$ & $\begin{array}{c}55.03^{* * *} \\
(15.42)\end{array}$ & $\begin{array}{c}53.27^{* * *} \\
(15.25)\end{array}$ & $\begin{array}{c}54.26^{* * *} \\
(15.25)\end{array}$ & $\begin{array}{c}54.28^{* * *} \\
(15.25)\end{array}$ \\
\hline intercept & $\begin{array}{c}141.5^{* * *} \\
(23.62)\end{array}$ & $\begin{array}{c}143.5^{* * *} \\
(24.39) \\
\end{array}$ & $\begin{array}{c}142.1^{* * *} \\
(23.48)\end{array}$ & $\begin{array}{c}155.3^{* * *} \\
(25.13)\end{array}$ & $\begin{array}{c}121.9^{* * *} \\
(27.35)\end{array}$ & $\begin{array}{c}139.2^{* * *} \\
(24.47) \\
\end{array}$ \\
\hline Number of Observations & 658 & 658 & 658 & 658 & 658 & 658 \\
\hline$\chi^{2}$ statistic & 67.66 & 67.82 & 67.95 & 71.30 & 70.81 & 70.70 \\
\hline Pseudo $R^{2}$ & 0.0085 & 0.0085 & 0.0085 & 0.0089 & 0.0088 & 0.0088 \\
\hline Log Likelihood & -3968 & -3968 & -3968 & -3966 & -3966 & -3966 \\
\hline
\end{tabular}


Table 9

Determinants of Frequency of Contact with Husband's Parents

\begin{tabular}{|c|c|c|c|c|c|c|}
\hline \multirow[b]{2}{*}{ Explanatory Variables } & \multicolumn{6}{|c|}{ Specification } \\
\hline & (1) & (2) & $(3)$ & $(4)$ & (5) & (6) \\
\hline inheritance expectations & $\begin{array}{c}30.68^{* * *} \\
(11.11)\end{array}$ & & & & & \\
\hline altruism & & $\begin{array}{c}0.757 \\
(6.964)\end{array}$ & $\begin{array}{c}0.753 \\
(6.964)\end{array}$ & $\begin{array}{c}0.935 \\
(6.906)\end{array}$ & $\begin{array}{c}0.564 \\
(6.992)\end{array}$ & $\begin{array}{c}0.302 \\
(6.980)\end{array}$ \\
\hline (inheritance expectations) & & $30.16^{*}$ & $29.94^{*}$ & $29.42^{*}$ & $30.22^{*}$ & $30.83^{*}$ \\
\hline$\times($ altruism $)$ & & $(17.24)$ & $(17.26)$ & $(17.10)$ & $(17.24)$ & $(17.25)$ \\
\hline (inheritance expectations) & & $30.91^{* *}$ & $30.80^{* *}$ & $33.37^{* *}$ & $30.78^{* *}$ & $30.90^{* *}$ \\
\hline$\times($ exchange motive $)$ & & $(14.17)$ & $(14.15)$ & $(14.07)$ & $(14.18)$ & $(14.17)$ \\
\hline inheritance experience & $\begin{array}{c}27.90^{* * *} \\
(10.00)\end{array}$ & $\begin{array}{c}27.91^{* * *} \\
(10.02)\end{array}$ & $\begin{array}{c}27.90^{* * *} \\
(10.02)\end{array}$ & $\begin{array}{c}27.26^{* * *} \\
(9.945)\end{array}$ & $\begin{array}{c}28.00^{* * *} \\
(10.03)\end{array}$ & $\begin{array}{c}27.73^{* * *} \\
(10.02)\end{array}$ \\
\hline parental assistance expectations & $\begin{array}{c}5.818 \\
(9.145)\end{array}$ & $\begin{array}{c}5.764 \\
(9.159)\end{array}$ & $\begin{array}{c}5.726 \\
(9.153)\end{array}$ & $\begin{array}{c}5.890 \\
(9.083)\end{array}$ & $\begin{array}{c}5.676 \\
(9.163)\end{array}$ & $\begin{array}{c}5.538 \\
(9.158)\end{array}$ \\
\hline have a grandchild & $\begin{array}{l}-2.492 \\
(10.44)\end{array}$ & $\begin{array}{l}-2.509 \\
(10.45)\end{array}$ & & & & \\
\hline number of grandchildren & & & $\begin{array}{l}-1.136 \\
(3.508)\end{array}$ & & & \\
\hline (have a grandchild) & & & & -2.793 & & \\
\hline × (co-resident $)$ & & & & $(10.36)$ & & \\
\hline (have a grandchild) & & & & $46.07^{* * *}$ & & \\
\hline × (living apart) & & & & $(17.70)$ & & \\
\hline (have a grandchild) & & & & & -1.339 & \\
\hline × (pre-nursery school age) & & & & & (11.11) & \\
\hline (have a grandchild) & & & & & -3.985 & \\
\hline$\times$ (nursery school age and older) & & & & & (11.49) & \\
\hline $\begin{array}{l}\text { (have a grandchild) } \\
\times(\text { pre-nursery school age })\end{array}$ & & & & & & $\begin{array}{l}12.25 \\
(19.71)\end{array}$ \\
\hline $\begin{array}{l}\times(\text { dual earner }) \\
(\text { have a grandchild }) \\
\times(\text { otherwise })\end{array}$ & & & & & & $\begin{array}{l}-3.863 \\
(10.55)\end{array}$ \\
\hline income & $\begin{array}{c}-0.025^{* *} \\
(0.014)\end{array}$ & $\begin{array}{c}-0.025^{*} \\
(0.014)\end{array}$ & $\begin{array}{c}-0.025^{*} \\
(0.014)\end{array}$ & $\begin{array}{c}-0.024^{*} \\
(0.014)\end{array}$ & $\begin{array}{c}-0.025^{*} \\
(0.014)\end{array}$ & $\begin{array}{c}-0.025^{*} \\
(0.014)\end{array}$ \\
\hline have a housing loan & $\begin{array}{c}2.824 \\
(7.086)\end{array}$ & $\begin{array}{c}2.838 \\
(7.090)\end{array}$ & $\begin{array}{c}2.941 \\
(7.101)\end{array}$ & $\begin{array}{c}5.265 \\
(7.067)\end{array}$ & $\begin{array}{c}2.971 \\
(7.102)\end{array}$ & $\begin{array}{c}2.673 \\
(7.088)\end{array}$ \\
\hline dual earner & $\begin{array}{c}5.564 \\
(7.899)\end{array}$ & $\begin{array}{c}5.595 \\
(7.904)\end{array}$ & $\begin{array}{c}5.456 \\
(7.928)\end{array}$ & $\begin{array}{c}4.260 \\
(7.848)\end{array}$ & $\begin{array}{c}5.803 \\
(7.932)\end{array}$ & $\begin{array}{c}2.922 \\
(8.459)\end{array}$ \\
\hline female & $\begin{array}{c}-15.98^{* *} \\
(8.617)\end{array}$ & $\begin{array}{c}-15.94^{*} \\
(8.624)\end{array}$ & $\begin{array}{c}-15.85^{*} \\
(8.627)\end{array}$ & $\begin{array}{c}-16.70^{*} \\
(8.556)\end{array}$ & $\begin{array}{c}-15.59^{*} \\
(8.699)\end{array}$ & $\begin{array}{c}-15.60^{*} \\
(8.628)\end{array}$ \\
\hline age & $\begin{array}{l}-1.234^{* * *} \\
(0.395)\end{array}$ & $\begin{array}{l}-1.235^{* * *} \\
(0.395)\end{array}$ & $\begin{array}{l}-1.224^{* * *} \\
(0.397)\end{array}$ & $\begin{array}{c}-1.699^{* * *} \\
(0.415)\end{array}$ & $\begin{array}{l}-1.158^{* *} \\
(0.466)\end{array}$ & $\begin{array}{c}-1.170^{* * *} \\
(0.401)\end{array}$ \\
\hline $\begin{array}{l}\text { agriculture, fishery, } \\
\text { or mining }\end{array}$ & $\begin{array}{c}13.94 \\
(25.59)\end{array}$ & $\begin{array}{c}14.09 \\
(25.63)\end{array}$ & $\begin{array}{c}14.68 \\
(25.74)\end{array}$ & $\begin{array}{c}15.24 \\
(25.43)\end{array}$ & $\begin{array}{c}14.10 \\
(25.63)\end{array}$ & $\begin{array}{c}14.86 \\
(25.60)\end{array}$ \\
\hline self-employment & $\begin{array}{c}61.95^{* * *} \\
(11.09)\end{array}$ & $\begin{array}{c}61.94^{* * *} \\
(11.11)\end{array}$ & $\begin{array}{c}62.40^{* * *} \\
(11.21)\end{array}$ & $\begin{array}{c}60.88^{* * *} \\
(11.02)\end{array}$ & $\begin{array}{c}61.97^{* * *} \\
(11.11)\end{array}$ & $\begin{array}{c}62.04^{* * *} \\
(11.10)\end{array}$ \\
\hline intercept & $\begin{array}{c}92.40^{* * *} \\
(17.08) \\
\end{array}$ & $\begin{array}{c}92.87^{* * *} \\
(17.63) \\
\end{array}$ & $\begin{array}{c}92.11^{* * *} \\
(16.98) \\
\end{array}$ & $\begin{array}{c}108.2^{* * *} \\
(18.07)\end{array}$ & $\begin{array}{c}90.07^{* * *} \\
(19.82) \\
\end{array}$ & $\begin{array}{c}91.24^{* * *} \\
(17.72) \\
\end{array}$ \\
\hline Number of Observations & 658 & 658 & 658 & 658 & 658 & 658 \\
\hline$\chi^{2}$ statistic & 70.46 & 70.47 & 70.52 & 81.85 & 70.57 & 71.25 \\
\hline Pseudo $R^{2}$ & 0.0099 & 0.0099 & 0.0099 & 0.011 & 0.010 & 0.010 \\
\hline Log Likelihood & -3508 & -3508 & -3508 & -3503 & -3508 & -3508 \\
\hline
\end{tabular}


Table 10

Marginal Effects on the Probability of Co-residence with Parents or Parents-in-Law

\begin{tabular}{|c|c|c|c|c|c|c|c|c|c|c|c|}
\hline Explanatory Variables & $(1)$ & $(2)$ & $(3)$ & $(4)$ & $\begin{array}{c}\text { Sample } \\
(5)\end{array}$ & $(6)$ & $(7)$ & $(8)$ & $(9)$ & $(10)$ & (11) \\
\hline (inheritance expectations) & $0.333^{* * *}$ & $0.373^{* * *}$ & $0.214^{*}$ & $0.305^{* * *}$ & $0.280^{* * *}$ & $0.167^{*}$ & $0.362^{* * *}$ & 0.179 & $0.367^{* *}$ & $0.528^{* *}$ & -0.013 \\
\hline$\times($ altruism $)$ & $(0.080)$ & $(0.108)$ & $(0.123)$ & $(0.082)$ & $(0.082)$ & $(0.070)$ & $(0.105)$ & $(0.123)$ & $(0.144)$ & $(0.135)$ & $(0.218)$ \\
\hline (inheritance expectations) & $0.487^{* * *}$ & $0.371^{* * *}$ & $0.584^{* * *}$ & $0.491^{* * *}$ & $0.452^{* * *}$ & $0.254^{* * *}$ & $0.373^{* * *}$ & $0.577^{* * *}$ & $0.481^{* * *}$ & $0.404^{* * *}$ & $0.595^{* * *}$ \\
\hline$\times($ exchange motive $)$ & $(0.050)$ & $(0.084)$ & $(0.060)$ & $(0.049)$ & $(0.047)$ & $(0.040)$ & $(0.086)$ & $(0.059)$ & $(0.074)$ & $(0.109)$ & $(0.102)$ \\
\hline \multirow[t]{2}{*}{ inheritance experience } & 0.022 & 0.056 & -0.011 & 0.0003 & -0.006 & -0.090 & 0.039 & -0.029 & -0.040 & -0.035 & -0.041 \\
\hline & $(0.047)$ & $(0.072)$ & $(0.063)$ & $(0.052)$ & $(0.061)$ & $(0.068)$ & $(0.084)$ & $(0.065)$ & $(0.066)$ & $(0.092)$ & $(0.101)$ \\
\hline \multirow[t]{2}{*}{ parental assistance expectations } & -0.025 & -0.030 & -0.045 & -0.035 & -0.035 & -0.053 & -0.053 & -0.049 & -0.136 & 0.159 & 0.022 \\
\hline & $(0.049)$ & $(0.072)$ & $(0.069)$ & $(0.069)$ & $(0.055)$ & $(0.068)$ & $(0.085)$ & $(0.074)$ & $(0.098)$ & $(0.127)$ & $(0.161)$ \\
\hline \multirow[t]{2}{*}{ have a grandchild } & 0.080 & 0.088 & 0.083 & 0.102 & 0.054 & 0.137 & 0.114 & 0.095 & 0.166 & 0.180 & 0.152 \\
\hline & $(0.054)$ & $(0.071)$ & $(0.085)$ & $(0.061)$ & $(0.085)$ & $(0.115)$ & $(0.087)$ & $(0.090)$ & $(0.103)$ & $(0.127)$ & $(0.213)$ \\
\hline Number of Observations & 943 & 436 & 507 & 813 & 642 & 414 & 343 & 470 & 439 & 242 & 197 \\
\hline
\end{tabular}

Column 1 shows the same estimation results as column 2 in Table 7. Columns 2 through 8 show the estimation results for the same specification as column 1 in this table and column 2 in Table 7 using various subsamples. Columns 2 and 3 show the results for the subsamples of males and females, respectively. Columns 4 through 6 show the results excluding respondents who are not able to travel to and from their own residence and either their parents' or in-laws' residence in one day, respondents who are not able to arrive at either their parents' or in-laws' residence within one hour by car, bus, or train, and respondents who do not live within walking distance between respondent's own residence and either their parents or parents-in-law, respectively. Columns 7 and 8 show the results for the subsamples of males and females, respectively, excluding respondents who are not able to travel to and from their own residence and either of their parents' or in-laws' residence in one day. Column 9 shows the results for the subsample of those who are forty and older. Columns 10 and 11 show the results for the forty and older subsamples of males and females, respectively. 
Table 11

Determinants of Distance between Respondent's Residence and That of Parents Who Live Closer to Respondent

\begin{tabular}{|c|c|c|c|c|c|c|c|c|c|c|c|c|}
\hline \multirow[b]{2}{*}{ Explanatory Variables } & \multicolumn{12}{|c|}{ Sample } \\
\hline & (1) & $(2)$ & $(3)$ & $(4)$ & $(5)$ & $(6)$ & $(7)$ & $(8)$ & $(9)$ & $(10)$ & $(11)$ & $(12)$ \\
\hline (inheritance expectations) & 0.332 & 0.487 & 0.318 & 0.131 & 0.105 & $0.826^{*}$ & -0.198 & 0.315 & 0.456 & 0.479 & 0.211 & 0.641 \\
\hline$\times($ altruism $)$ & $(0.234)$ & $(0.346)$ & $(0.337)$ & $(0.260)$ & $(0.380)$ & $(0.429)$ & $(0.352)$ & $(0.241)$ & $(0.285)$ & $(0.347)$ & $(0.358)$ & $(0.559)$ \\
\hline (inheritance expectations) & 0.270 & 0.221 & 0.407 & $0.394^{*}$ & 0.441 & 0.472 & 0.443 & 0.156 & -0.036 & 0.029 & 0.421 & 0.353 \\
\hline$\times($ exchange motive $)$ & $(0.194)$ & $(0.273)$ & $(0.283)$ & $(0.227)$ & $(0.289)$ & $(0.380)$ & $(0.296)$ & $(0.205)$ & $(0.249)$ & $(0.281)$ & $(0.316)$ & $(0.333)$ \\
\hline \multirow[t]{2}{*}{ inheritance experience } & $0.278^{* *}$ & 0.135 & $0.392^{* *}$ & 0.159 & 0.217 & 0.018 & 0.240 & $0.367^{* * *}$ & 0.101 & 0.047 & $0.649^{* * *}$ & $0.350^{*}$ \\
\hline & $(0.136)$ & $(0.213)$ & $(0.182)$ & $(0.154)$ & $(0.204)$ & $(0.279)$ & $(0.190)$ & $(0.141)$ & $(0.177)$ & $(0.216)$ & $(0.196)$ & $(0.186)$ \\
\hline \multirow[t]{2}{*}{ parental assistance expectations } & -0.024 & 0.158 & -0.126 & -0.129 & -0.182 & -0.040 & -0.110 & -0.0036 & 0.079 & 0.154 & -0.052 & -0.017 \\
\hline & $(0.123)$ & $(0.184)$ & $(0.170)$ & $(0.143)$ & $(0.212)$ & $(0.235)$ & $(0.186)$ & $(0.125)$ & $(0.147)$ & $(0.185)$ & $(0.174)$ & $(0.267)$ \\
\hline \multirow[t]{2}{*}{ have a grandchild } & -0.030 & -0.010 & -0.083 & 0.165 & -0.129 & 0.343 & -0.013 & -0.0012 & 0.024 & 0.0017 & -0.015 & 0.090 \\
\hline & $(0.141)$ & $(0.193)$ & $(0.215)$ & $(0.167)$ & $(0.254)$ & $(0.257)$ & $(0.229)$ & $(0.144)$ & $(0.165)$ & $(0.194)$ & $(0.224)$ & $(0.313)$ \\
\hline Number of Observations & 658 & 299 & 359 & 528 & 357 & 206 & 322 & 644 & 529 & 298 & 346 & 290 \\
\hline
\end{tabular}

Columns 2 through 11 show the estimation results for the same specification as column 1 in this table and column 2 in Table 8 using various subsamples. Columns 2 and 3 show the results for the subsamples of males and females, respectively. Columns 4 and 5 show the results for the sample excluding respondents who are not able to travel to and from their own residence and either their parents' or in-laws' residence in one day and respondents who are not able to arrive at either their parents' or in-laws' residence within one hour by car, bus, or train, respectively. Columns 6 and 7 show the results

for the subsamples of males and females, respectively, excluding respondents who are not able to travel to and from their own residence and either their parents' or in-laws' residence in one day. Columns 8 and 9 show the results for the sample excluding respondents who live adjacent to their parents or parents-in-law and respondents who live within walking distance of either their parents or parents-in-law, respectively. Columns 10 and 11 show the results for the subsamples of males and females, respectively, excluding respondents who live adjacent to their parents or parents-in-law. Column 12 shows the results for the subsample of those who are forty and older. 
Table 12

Determinants of Distance between Respondent's Residence and That of the Husband's Parents

\begin{tabular}{|c|c|c|c|c|c|c|c|c|c|c|c|c|}
\hline \multirow[b]{2}{*}{ Explanatory Variables } & \multicolumn{12}{|c|}{ Sample } \\
\hline & $(1)$ & $(2)$ & $(3)$ & $(4)$ & $(5)$ & $(6)$ & $(7)$ & $(8)$ & $(9)$ & (10) & $(11)$ & $(12)$ \\
\hline (inheritance expectations) & $0.438^{*}$ & 0.528 & 0.517 & 0.364 & 0.460 & $0.768^{*}$ & 0.305 & 0.419 & 0.419 & 0.521 & 0.412 & 0.801 \\
\hline$\times($ altruism $)$ & $(0.232)$ & $(0.337)$ & $(0.339)$ & $(0.251)$ & $(0.312)$ & $(0.406)$ & $(0.343)$ & $(0.237)$ & $(0.259)$ & $(0.337)$ & $(0.357)$ & $(0.558)$ \\
\hline (inheritance expectations) & $0.488^{* * *}$ & 0.380 & $0.692^{* *}$ & $0.460^{* *}$ & $0.620^{* *}$ & -0.014 & $0.756^{* * *}$ & $0.420^{\text {** }}$ & 0.320 & 0.302 & $0.732^{* *}$ & $0.610^{*}$ \\
\hline$\times($ exchange motive $)$ & $(0.190)$ & $(0.263)$ & $(0.281)$ & $(0.218)$ & $(0.265)$ & $(0.364)$ & $(0.292)$ & $(0.196)$ & $(0.233)$ & $(0.268)$ & $(0.310)$ & $(0.328)$ \\
\hline \multirow[t]{2}{*}{ inheritance experience } & $0.447^{* * *}$ & $0.569^{* * *}$ & $0.374^{* *}$ & $0.374^{* *}$ & $0.348^{*}$ & $0.726^{* * *}$ & 0.247 & $0.504^{* * *}$ & $0.466^{* * *}$ & $0.537^{* *}$ & $0.504^{* * *}$ & $0.473^{* * *}$ \\
\hline & $(0.134)$ & $(0.208)$ & $(0.180)$ & $(0.148)$ & $(0.180)$ & $(0.263)$ & $(0.185)$ & $(0.136)$ & $(0.164)$ & $(0.209)$ & $(0.188)$ & $(0.184)$ \\
\hline \multirow[t]{2}{*}{ parental assistance expectations } & 0.012 & 0.193 & -0.145 & -0.057 & -0.153 & 0.030 & -0.149 & 0.045 & 0.084 & 0.190 & -0.089 & 0.194 \\
\hline & $(0.123)$ & $(0.180)$ & $(0.171)$ & $(0.135)$ & $(0.174)$ & $(0.220)$ & $(0.182)$ & $(0.123)$ & $(0.138)$ & $(0.180)$ & $(0.173)$ & $(0.264)$ \\
\hline \multirow[t]{2}{*}{ have a grandchild } & 0.104 & 0.193 & -0.073 & $0.259^{*}$ & 0.043 & $0.605^{* *}$ & -0.016 & 0.133 & 0.126 & 0.200 & -0.003 & 0.291 \\
\hline & $(0.141)$ & $(0.190)$ & $(0.216)$ & $(0.156)$ & $(0.212)$ & $(0.246)$ & $(0.224)$ & $(0.142)$ & $(0.156)$ & $(0.190)$ & $(0.222)$ & $(0.313)$ \\
\hline Number of Observations & 658 & 299 & 359 & 528 & 357 & 206 & 322 & 644 & 529 & 298 & 346 & 290 \\
\hline
\end{tabular}

Column 1 shows the same estimation results as column 2 in Table 9. Columns 2 through 11 show the estimation results for the same specification as column 1 in this table and column 2 in Table 9 using various subsamples. The subsamples used are the same as in Table 13. 
Table 13

Determinants of Frequency of Contact with Parents or Parents-in-Law

\begin{tabular}{|c|c|c|c|c|c|c|c|c|c|c|c|c|}
\hline Explanatory Variables & (1) & $(2)$ & $(3)$ & $(4)$ & $(5)$ & $\begin{array}{c}\text { Sample } \\
(6)\end{array}$ & (7) & $(8)$ & (9) & $(10)$ & (11) & $(12)$ \\
\hline (inheritance expectations) & 15.74 & 18.84 & 5.406 & 6.001 & 6.083 & 28.20 & -8.126 & 10.73 & 5.428 & 19.44 & -3.482 & 44.71 \\
\hline$\times($ altruism $)$ & $(22.96)$ & $(29.71)$ & $(37.64)$ & $(27.25)$ & $(35.12)$ & $(37.50)$ & $(38.86)$ & $(23.41)$ & $(21.27)$ & $(29.71)$ & $(36.70)$ & $(48.70)$ \\
\hline (inheritance expectations) & 23.83 & 40.72 & 13.64 & 21.64 & 25.07 & 46.07 & 13.91 & 24.96 & 15.89 & $45.53^{*}$ & 7.009 & 19.71 \\
\hline$\times($ exchange motive $)$ & $(19.60)$ & $(23.28)$ & $(31.01)$ & $(23.67)$ & $(29.96)$ & $(32.51)$ & $(32.80)$ & $(19.26)$ & $(19.09)$ & $(23.76)$ & $(29.82)$ & $(28.57)$ \\
\hline \multirow[t]{2}{*}{ inheritance experience } & $42.63^{* * *}$ & $32.04^{*}$ & $48.90^{* *}$ & $38.99^{* *}$ & $48.51^{* *}$ & 25.62 & $41.79^{* *}$ & $49.84^{* * *}$ & $28.79^{* *}$ & $34.19^{*}$ & $61.84^{* * *}$ & $44.17^{* * *}$ \\
\hline & $(13.82)$ & $(18.28)$ & $(20.10)$ & $(16.06)$ & $(20.58)$ & $(24.28)$ & $(20.98)$ & $(13.37)$ & $(13.53)$ & $(18.40)$ & $(18.87)$ & $(16.18)$ \\
\hline \multirow[t]{2}{*}{ parental assistance expectations } & 7.689 & $38.66^{* *}$ & -15.42 & 6.898 & 5.071 & $44.62^{* *}$ & -17.31 & 11.19 & 11.73 & $38.89^{* *}$ & -7.179 & 17.68 \\
\hline & $(12.62)$ & $(15.98)$ & $(18.85)$ & $(14.69)$ & $(19.73)$ & $(19.81)$ & $(20.65)$ & $(12.14)$ & $(11.27)$ & $(15.98)$ & $(17.64)$ & $(23.14)$ \\
\hline \multirow[t]{2}{*}{ have a grandchild } & -4.816 & -17.47 & 9.411 & 1.982 & -8.606 & -11.51 & 12.28 & -3.630 & -2.116 & -17.81 & 14.32 & -39.15 \\
\hline & $(14.44)$ & $(16.70)$ & $(23.91)$ & $(16.88)$ & $(24.06)$ & $(21.21)$ & $(25.39)$ & $(13.96)$ & $(12.79)$ & $(16.70)$ & $(22.63)$ & $(26.81)$ \\
\hline Number of Observations & 658 & 299 & 359 & 528 & 357 & 206 & 322 & 644 & 529 & 298 & 346 & 290 \\
\hline
\end{tabular}

Column 1 shows the same estimation results as column 2 in Table 10. Columns 2 through 11 show the estimation results for the same specification as column 1 in this table and column 2 in Table 10 using various subsamples. The subsamples used are the same as in Tables 13 and 14. 
Table 14

Determinants of Frequency of Contact with Husband's Parents

\begin{tabular}{|c|c|c|c|c|c|c|c|c|c|c|c|c|}
\hline \multirow[b]{2}{*}{ Explanatory Variables } & \multicolumn{12}{|c|}{ Sample } \\
\hline & (1) & $(2)$ & $(3)$ & $(4)$ & $(5)$ & $(6)$ & $(7)$ & (8) & $(9)$ & $(10)$ & $(11)$ & $(12)$ \\
\hline (inheritance expectations) & $30.16^{*}$ & 27.37 & 36.81 & 31.87 & 42.44 & 41.17 & 32.11 & 23.38 & 13.79 & 27.96 & 21.03 & $87.59^{* *}$ \\
\hline$\times($ altruism $)$ & $(17.24)$ & $(24.39)$ & $(24.83)$ & $(20.05)$ & $(26.83)$ & $31.50)$ & $(26.20)$ & $(15.94)$ & $(15.10)$ & $(24.38)$ & $(20.99)$ & $(37.22)$ \\
\hline (inheritance expectations) & $30.91^{* *}$ & 28.27 & $37.69^{*}$ & $31.91^{*}$ & $43.04^{*}$ & 23.56 & $40.35^{*}$ & $28.31^{* *}$ & $27.03^{* *}$ & $33.03^{*}$ & 26.60 & 13.46 \\
\hline$\times($ exchange motive $)$ & $(14.17)$ & $(19.15)$ & $(20.49)$ & $(17.47)$ & $(23.02)$ & $(27.42)$ & $(22.16)$ & $(13.14)$ & $(13.58)$ & $(19.54)$ & $(17.08)$ & $(21.67)$ \\
\hline \multirow[t]{2}{*}{ inheritance experience } & $27.91^{* * *}$ & $46.53^{* * *}$ & 13.96 & $24.92^{* *}$ & $26.92^{*}$ & $50.18^{* *}$ & 10.72 & $32.52^{* * *}$ & $32.70^{* * *}$ & $48.72^{* * *}$ & $20.73^{* *}$ & $20.75^{*}$ \\
\hline & $(10.02)$ & $(15.14)$ & $(13.22)$ & $(11.82)$ & $(15.71)$ & $(20.60)$ & $(14.10)$ & $(9.134)$ & $(9.654)$ & $(15.24)$ & $(10.79)$ & $(12.31)$ \\
\hline \multirow[t]{2}{*}{ parental assistance expectations } & 5.764 & $28.95^{* *}$ & -16.30 & 6.746 & 4.768 & $33.87^{* *}$ & -16.26 & 9.164 & 12.92 & $29.17^{* *}$ & -8.393 & 27.02 \\
\hline & $(9.159)$ & $(13.17)$ & $(12.51)$ & $(10.81)$ & $(15.06)$ & $(16.72)$ & $(13.91)$ & $(8.312)$ & $(8.067)$ & $(13.16)$ & $(10.17)$ & $(17.82)$ \\
\hline \multirow[t]{2}{*}{ have a grandchild } & -2.509 & -8.876 & -1.248 & 0.163 & -16.15 & -7.766 & -0.147 & -1.244 & -1.092 & -9.216 & 4.929 & -2.352 \\
\hline & $(10.45)$ & $(13.71)$ & $(15.82)$ & $(12.45)$ & $(18.45)$ & $(17.81)$ & $(17.17)$ & $(9.531)$ & $(9.090)$ & $(13.71)$ & $(13.02)$ & $(20.57)$ \\
\hline Number of Observations & 658 & 299 & 359 & 528 & 357 & 206 & 322 & 644 & 529 & 298 & 346 & 290 \\
\hline
\end{tabular}

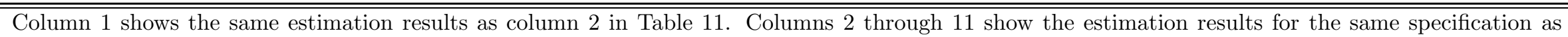
column 1 in this table and column 2 in Table 11 using various subsamples. The subsamples used are the same as Tables 13 through 15. 